\title{
Recent Progress and New Perspectives on Metal Amide and Imide Systems for Solid-State Hydrogen Storage
}

\author{
Sebastiano Garroni ${ }^{1, *}$, Antonio Santoru ${ }^{2}$, Hujun Cao ${ }^{2}$, Martin Dornheim ${ }^{2}$, Thomas Klassen ${ }^{2,3}$, \\ Chiara Milanese ${ }^{4}$, Fabiana Gennari ${ }^{5}$ and Claudio Pistidda ${ }^{2, *}$ (D) \\ 1 International Research Centre in Critical Raw Materials-ICCRAM, Universidad de Burgos, Plaza Misael \\ Banuelos s/n, 09001 Burgos, Spain \\ 2 Institute of Materials Research, Materials Technology, Helmholtz-Zentrum Geesthacht GmbH, \\ Max-Planck-Straße 1, 21502 Geesthacht, Germany; Antonio.Santoru@hzg.de (A.S.); \\ Hujun.Cao@hzg.de (H.C.); martin.dornheim@hzg.de (M.D.); Thomas.Klassen@hzg.de (T.K.) \\ 3 Department of Mechanical Engineering, Helmut Schmidt University, Holstenhofweg 85, \\ Hamburg 22043, Germany \\ 4 Pavia Hydrogen Lab, C.S.G.I. \& Department of Chemistry, Physical-Chemistry Section, University of Pavia, \\ Viale Taramelli, 16, 27100 Pavia, Italy; chiara.milanese@unipv.it \\ 5 Centro Atómico Bariloche (CNEA) e Instituto Balseiro (UNCuyo), Bariloche, Río \\ Negro R8402AGP, Argentina; gennari@cab.cnea.gov.ar \\ * Correspondence: sgarroni@ubu.es (S.G.); Claudio.Pistidda@hzg.de (C.P.); Tel.: +34-653-082-964 (S.G.); \\ +49-(0)-4152-87-2644 (C.P.)
}

Received: 28 February 2018; Accepted: 19 April 2018; Published: 24 April 2018

\begin{abstract}
Hydrogen storage in the solid state represents one of the most attractive and challenging ways to supply hydrogen to a proton exchange membrane (PEM) fuel cell. Although in the last 15 years a large variety of material systems have been identified as possible candidates for storing hydrogen, further efforts have to be made in the development of systems which meet the strict targets of the Fuel Cells and Hydrogen Joint Undertaking (FCH JU) and U.S. Department of Energy (DOE). Recent projections indicate that a system possessing: (i) an ideal enthalpy in the range of 20-50 kJ/mol $\mathrm{H}_{2}$, to use the heat produced by PEM fuel cell for providing the energy necessary for desorption; (ii) a gravimetric hydrogen density of $5 \mathrm{wt} . \% \mathrm{H}_{2}$ and (iii) fast sorption kinetics below $110^{\circ} \mathrm{C}$ is strongly recommended. Among the known hydrogen storage materials, amide and imide-based mixtures represent the most promising class of compounds for on-board applications; however, some barriers still have to be overcome before considering this class of material mature for real applications. In this review, the most relevant progresses made in the recent years as well as the kinetic and thermodynamic properties, experimentally measured for the most promising systems, are reported and properly discussed.
\end{abstract}

Keywords: hydrogen storage materials; metal amides; thermodynamics and kinetics

\section{Introduction}

The constant growth in world population coupled with the rapid industrialization of the developing countries could lead to a drastic increase in the number of light-duty vehicles from now to 2050. Considering that the majority of the vehicles are currently based on the internal combustion engine (ICE) technology, the transportation sector is strongly dependent on petroleum-derived fuels which represent one of the biggest causes of carbon dioxide emission. In 2008, passenger cars were responsible for $17 \%$ of $\mathrm{CO}_{2}$ emissions in the European Union. For these reasons, clean and 
environmentally-friendly energy alternative carriers to the fossil fuels, capable of stabilizing global $\mathrm{CO}_{2}$ level while sustaining the global mobility demand are desired. In this context, the "green" hydrogen fuel cell vehicles (FCVs) represent promising alternatives to the gasoline ICE. In order to achieve an extensive commercialization of hydrogen-powered cars, some obstacles have still to be overcome. Among them, the pressing issue is for on-board hydrogen storage in safe and efficient manner and, in this frame, hydrogen storage in solid state is considered as one of the most promising solution, as verified by the numerous studies all over the world focused on finding materials meeting the requirements for on-board applications established by the European Fuel Cell \& Hydrogen Technology Platform and the US Department of Energy (DoE). For example, in proton exchange membrane fuel cells (PEMFC), hydrogen is supposed to be delivered under temperature below $90^{\circ} \mathrm{C}$, which implies the use materials with $\Delta \mathrm{H}_{\text {des }}$ between $20-50 \mathrm{~kJ} / \mathrm{mol} \mathrm{H}_{2}$ and $\Delta \mathrm{S}_{\text {des }}$ between $100-130 \mathrm{~J} /\left(\mathrm{mol} \mathrm{H}_{2} \mathrm{~K}\right)$ in order to reach 1 bar equilibrium hydrogen pressure.

Recently, many systems based on solid-state hydrogen storage materials have been tested in laboratory or on mobile prototypes. However, the parameters evaluated in laboratory tests were usually not suitable, in terms of gravimetric capacity and kinetics, for most light-duty passenger vehicles.

Since its discovery in 2002, the $\mathrm{LiNH}_{2}-\mathrm{LiH}$ system [1] and in general amides and imides, have attracted more and more attentions as promising hydrogen storage materials, becoming one of the principal candidates for onboard applications on light-duty vehicles [2]. As shown in Figure 1, during the last 15 years, more than 300 among peer-reviewed papers and books have been published in the field of solid-state hydrogen storage, concerning this class of complex hydrides characterized by $\mathrm{N}-\mathrm{H}$ bonds.

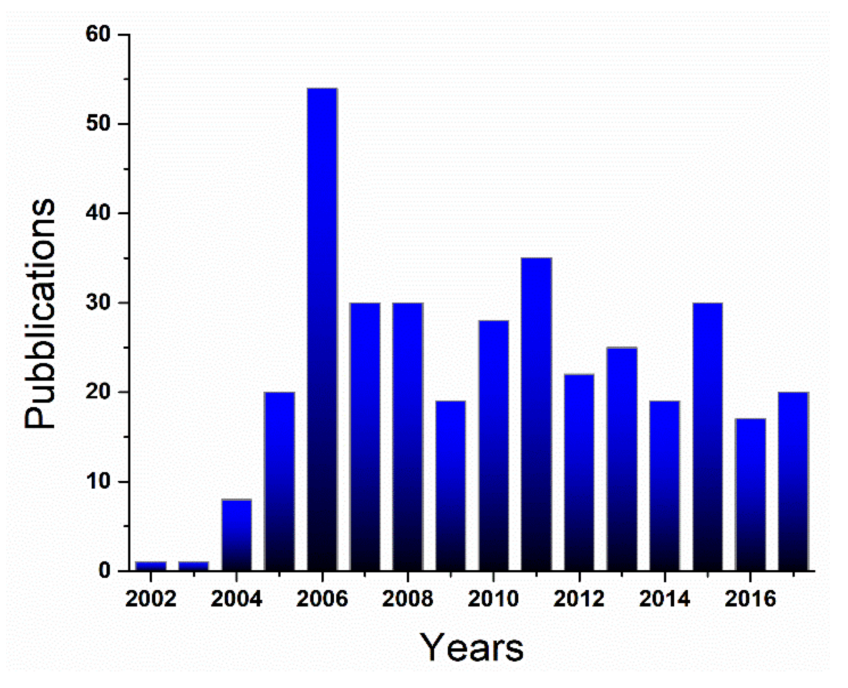

Figure 1. Number of publications on amides/imides compounds in the hydrogen storage field. Scopus sources. Www.scopus.com.

From the picture in Figure 1, it is also possible to evince a constant and still actual fervent interest in amides/imides compounds for hydrogen storage purposes. This specific attention can be motivated by the fact that these systems can store sufficient amount of hydrogen in terms of gravimetric and volumetric densities, while possessing promising thermodynamic and kinetic properties with respect to the other classes of complex hydrides [2].

From a general and scientific point of view, most of the metal amide/imide systems exhibit endothermic hydrogen desorption with partial or full reversibility. Among them the $\mathrm{Mg}\left(\mathrm{NH}_{2}\right)_{2}-2 \mathrm{LiH}$ composite possess high reversible hydrogen storage capacity (i.e., $5.0 \mathrm{wt}$. \%) together with suitable thermodynamic properties (i.e., $\Delta \mathrm{H}_{\text {des }} \approx 39 \mathrm{~kJ} / \mathrm{mol} \mathrm{H} \mathrm{H}_{2}$ and $\Delta \mathrm{S}_{\mathrm{des}}=112 \mathrm{~J} / \mathrm{mol} \mathrm{H}_{2} \mathrm{~K}$ ), optimal parameters for on-board application in fuel cell vehicles (FCVs). However, for technological applications, an important barrier is the poor kinetic rate during the dehydrogenation process. This is 
mainly due to the high activation energy, which can be opportunely modulated by different approaches, including the addition of catalysts and the reduction the particle size. Also in this context, significant progresses have been made in the last years on the amides/imides systems, reducing the activation energy to $\sim 80 \mathrm{~kJ} / \mathrm{mol}$, considered appealing for technological devices.

In this section, a detailed overview combined with the most recent progresses for different amides will be provided. Particular emphasis will be put on those systems with attractive features for practical applications.

\section{Li-N-H System}

One of the most interesting system, at present, is represented by the $\mathrm{LiNH}_{2}+\mathrm{LiH}$ mixture. When mixed, these substances show a reversible hydrogen storage capacity of $6.5 \mathrm{wt}$. \% combined with a working temperature below $300{ }^{\circ} \mathrm{C}\left(285^{\circ} \mathrm{C}\right)$ and appealing thermodynamic properties $\left(\Delta \mathrm{H}_{\mathrm{des}}=45 \mathrm{~kJ} / \mathrm{mol}\right)$ [1]. On the contrary, pure lithium amide and lithium hydride, separately, decompose at temperatures above $300{ }^{\circ} \mathrm{C}$ and $550{ }^{\circ} \mathrm{C}$, respectively [3]. In the first desorption mechanism proposed, the driving force is represented by the release of hydrogen as a consequence of the direct reaction between the $\mathrm{H}^{+}$in $\mathrm{LiNH}_{2}$ and $\mathrm{H}^{-}$in $\mathrm{LiH}$ to form $\mathrm{H}_{2}$ [4]. The second desorbing mechanism involves the decomposition of $\mathrm{LiNH}_{2}$ to $\frac{1}{2} \mathrm{Li}_{2} \mathrm{NH}$ and $\frac{1}{2} \mathrm{NH}_{3}$ (Equation (1)), while, in the second step, $\frac{1}{2} \mathrm{LiH}$ quickly reacts with $\frac{1}{2} \mathrm{NH}_{3}$ forming $\frac{1}{2} \mathrm{LiNH}_{2}$ and $\frac{1}{2} \mathrm{H}_{2}$ (Equation (2)) [5]:

$$
\begin{gathered}
\mathrm{LiNH}_{2} \leftrightarrow \frac{1}{2} \mathrm{Li}_{2} \mathrm{NH}+\frac{1}{2} \mathrm{NH}_{3} \\
\frac{1}{2} \mathrm{LiH}+\frac{1}{2} \mathrm{NH}_{3} \leftrightarrow \frac{1}{2} \mathrm{LiNH}_{2}+\frac{1}{2} \mathrm{H}_{2}
\end{gathered}
$$

Experimentally, in the temperature range of $180-400{ }^{\circ} \mathrm{C}$ this system desorbs hydrogen together with a large amount of ammonia, which should be avoided because it is the main responsible for the catalyst poisoning phenomenon in fuel cells [6-8]. Furthermore, it has been proved that the ammonia concentration brutally increases as the number of ab-desorption cycles increases, affecting the gravimetric capacity of the whole system [9]. Kiobayashi and coauthors reported that the starting hydrogen storage capacity of $5 \mathrm{wt}$. \% in the Li-N-H system decreases up to $2 \mathrm{wt}$. \% after 200 cycles tests at $300{ }^{\circ} \mathrm{C}$. This significant reduction of the gravimetric capacity can be, in fact, explained by the loss of nitrogen due to the ammonia release during cycles [9]. For these reasons, many attempts have been made to minimize the ammonia evolution and to drastically improve the poor sorption kinetic performance.

The working temperatures are, in fact, still too high to be practical for a PEM fuel cell, although the activation energies estimated by both Kissinger $(54 \mathrm{~kJ} / \mathrm{mol})$ and Arrhenius-plots $(56 \mathrm{~kJ} / \mathrm{mol})$ do not result so high with respect to the observed kinetic constraint [10]. In this regard, when $\mathrm{TiCl}_{3}(1 \mathrm{~mol} . \%)$ is added to the system, almost the $80 \%$ of hydrogen is desorbed (5.5 wt. \%) within $30 \mathrm{~min}$ at $200{ }^{\circ} \mathrm{C}$ and without ammonia release $[7,11]$. $\mathrm{TiCl}_{3}$ acts as a catalyst favoring the transfer of ammonia to lithium hydride and thus improves the hydrogen desorption kinetics of the $\mathrm{LiNH}_{2}-\mathrm{LiH}$ system. However, the activation energies calculated for the $\mathrm{TiCl}_{3}$-doped system $\left(95 \mathrm{~kJ} / \mathrm{mol}\right.$, for $1 \mathrm{~mol}$. \% $\left.\mathrm{TiCl}_{3}\right)$ resulted higher than that reported for the un-doped one [10]. In the latter, the small pre-exponential factor has the major effect, therefore it is possible to expect that in the pristine system the reaction occurs through different rate controlling steps. Homogeneous dispersion of Ti(III) species preserves the active surface of reactants and favors the reduction of $\mathrm{LiNH}_{2} / \mathrm{LiH}$ particles sizes by ball milling $[10,11]$. This last cited procedure has also an important effect on desorption behavior of the Li-N-H system. As reported by Lu et al. [12], the local Li electronic environment is strongly influenced by mechanical milling, which improves the hydrogen kinetic properties of the $\mathrm{LiNH}_{2}-\mathrm{LiH}$ composite. Mechanical milling, in fact, is an effective technique to reduce particle size, increase surface area and facilitate the formation of an intimate mixture between the two reagents, $\mathrm{LiNH}_{2}$ and $\mathrm{LiH}$. For example, Shaw and coauthors [13] proved that the hydrogen desorption temperature of $\mathrm{Li}-\mathrm{N}-\mathrm{H}$ in a molar ratio 1:1.1 can 
be decreased by high-energy ball milling. In this specific case, the onset dehydrogenation temperature to reach $1 \mathrm{wt}$. \% of released $\mathrm{H}_{2}$, is reduced from $300{ }^{\circ} \mathrm{C}$ in the unmilled material to $50{ }^{\circ} \mathrm{C}$ when the powders are subjected to $180 \mathrm{~min}$ of mechanical treatment. Furthermore, for the milled powders, no trace of ammonia gas is detected upon desorption. Activation energy seems to be also influenced by ball milling, although completely different values have been reported for the starting system by Shaw et al. with respect to a previous work of Matsumoto et al. [10].

More recently, again Shaw and coauthors [14] showed that milling at liquid nitrogen temperature $\left(-196^{\circ} \mathrm{C}\right)$ is effective in improving the kinetic performance of the powders during hydrogen desorption: the average diffusion rate increases by $450 \%$ by milling at liquid nitrogen temperature. Interestingly, the powders upon mechanical treatment at $-196{ }^{\circ} \mathrm{C}$ show crystallite sizes of 18.3 and $21.5 \mathrm{~nm}$ for $\mathrm{LiNH}_{2}$ and $\mathrm{LiH}$, respectively, much higher with respect to the values estimated for the systems milled at room temperature. Therefore, the significant improvement of the desorption kinetics cannot be ascribable to the particle size reduction but, most likely, to the large amount of lattice and surface defect accumulated during milling at low temperature. Another important issue which affects the kinetic properties of this system, is represented by the hydrolysis/oxidation of $\mathrm{LiH}$ into $\mathrm{LiOH}$ [15]. This reaction sequestrates the active amount of $\mathrm{LiH}$ able to convert $\mathrm{NH}_{3}$ to $\mathrm{LiNH}_{2}$ and $\mathrm{H}_{2}$ with a reduced hydrogen storage desorption performance. Varin et al. $[15,16]$ studied also the hydrogen storage properties of the $\mathrm{LiNH}_{2}-\mathrm{LiH}$ systems as a function of the milling time. They measured that the onset DSC (Differential Scanning Calorimetry) peak corresponding to the endothermic desorption step in the $1: 1$ mixture decreases from $325^{\circ} \mathrm{C}$ to $235^{\circ} \mathrm{C}$ when the sample is milled $25 \mathrm{~h}$, while in the powders further milled for $100 \mathrm{~h}$ the DSC signal is peaked at $245^{\circ} \mathrm{C}$. This is in agreement with the fact that during the milling the Brunauer-Emmett-Teller (BET) specific surface area (SSA) increases monotonically with increase of milling time up to $25 \mathrm{~h}\left(16.0,26.4,56.0\right.$ and $59.6 \mathrm{~m}^{2} / \mathrm{g}$ for the system milled at $0,1,5$ and $25 \mathrm{~h}$ ). On the other hand, upon $100 \mathrm{~h}$ of mechanical treatment, the value of SSA decreases to $45.6 \mathrm{~m}^{2} / \mathrm{g}$, probably due to powders agglomeration induced by the cold-welding process commonly produced in high-energy ball milling.

Another strategy adopted to improve the kinetic and thermodynamic properties of the $\mathrm{Li}-\mathrm{N}-\mathrm{H}$ system is represented by the addition of a second element [16,17] or compounds [16,18-21]. Nayebossadri [17] reported that elemental $\mathrm{Si}$ and $\mathrm{Al}$ can effectively improve the dehydrogenation rate of the $\mathrm{Li}-\mathrm{N}-\mathrm{H}$ system. In particular, the addition of $\mathrm{Si}$ decreases the dehydrogenation end-temperature by $200{ }^{\circ} \mathrm{C}$ compared to the pristine material. The destabilization effect can be attributed to the interaction between $\mathrm{LiH}$ and $\mathrm{Si}$, which forming the $\mathrm{Li}_{2} \mathrm{Si}$ phase increases the concentration of the $\mathrm{H}^{-}$ ions. Varin and coauthors [16], demonstrated that the system $\mathrm{LiNH}_{2}+1.2 \mathrm{LiH}+$ graphite (5 wt. \%) can absorb reversibly $5 \mathrm{wt}$. \% of $\mathrm{H}_{2}$ at $325{ }^{\circ} \mathrm{C}$. The inclusion of graphite in the $\mathrm{Li}-\mathrm{N}-\mathrm{H}$ matrix, guarantees an homogeneous heat transfer into the powders and, most important, seems to avoid the undesired hydrolysis/oxidation of LiH normally occurring in the ball milled mixture [16]. Ti- and B-based nitrides additives are also effective to produce a remarkable improvement in the dehydrogenation rate and desorption temperature of the $\mathrm{Li}-\mathrm{N}-\mathrm{H}$ system [19]. High concentration of TiN (35 wt. \%) seems to have a significant impact on the kinetic process lowering the activation energy from $163.76 \mathrm{~kJ} / \mathrm{mol}$ reported for the unmilled material to a promising value of $67.8 \mathrm{~kJ} / \mathrm{mol}$.

Structural studies on the Li-N-H system, by using synchrotron facilities as X-ray source, have been performed in order to clarify the reaction mechanism between $\mathrm{LiNH}_{2}$ and $\mathrm{LiH}$ [22,23]. David and coauthors, noted that the non-stoichiometric intermediates reported as $\mathrm{Li}_{1+x} \mathrm{NH}_{2-x}$ species are formed during desorption and absorption of the Li-N-H system, in accordance with the Frenkel defect model [24].

In the Li-N-H system, the poor sorption kinetics in both ab-desorption processes could be ascribable to a reduced $\mathrm{Li}^{+}$ion mobility $\left(\mathrm{Li}^{+}\right.$ion conductivity at room temperature is $10^{-8} \Omega^{-1} \mathrm{~cm}^{-1}$ ) [25]. In 2010, Orimo and coauthors [26] have successfully synthesized a new complex hydride $\mathrm{Li}_{3}\left(\mathrm{NH}_{2}\right)_{2} \mathrm{I}$ exhibiting lithium fast-ion conductivity of $1 \times 10^{-5} \Omega^{-1} \mathrm{~cm}^{-1}, 1000$ times higher than $\mathrm{LiNH}_{2}$. Along this way, Anderson et al. $[25,27,28]$ conducted a systematic study on the effects 
of different halides, $\mathrm{LiX}$ and $\mathrm{MgX}_{2}(\mathrm{X}=\mathrm{Cl}, \mathrm{I}, \mathrm{Br})$ on the hydrogen sorption properties of $\mathrm{LiNH}_{2}$ and $\mathrm{Li}_{2} \mathrm{NH}$. The new phases, $\mathrm{Li}_{4}\left(\mathrm{NH}_{2}\right)_{3} \mathrm{Cl}, \mathrm{Li}_{3} \mathrm{Mg}_{0.5}\left(\mathrm{NH}_{2}\right)_{3} \mathrm{Cl}$ and $\mathrm{Li}_{6} \mathrm{Mg}_{0.5}\left(\mathrm{NH}_{2}\right)_{6} \mathrm{Br}$, when heated with $\mathrm{LiH}$ are able to release hydrogen more rapidly than pristine $\mathrm{LiNH}_{2}$ and $\mathrm{LiNH}_{2}+\mathrm{LiH}$ system, with undetectable $\mathrm{NH}_{3}$ emission. The general desorption reaction is reported in Equation (3) [25]:

$$
\mathrm{Li}_{(1+\mathrm{n})}\left(\mathrm{NH}_{2}\right) \mathrm{X}_{\mathrm{n}}+\mathrm{LiH} \rightarrow \mathrm{Li}_{(2+\mathrm{n})}(\mathrm{NH}) \mathrm{X}_{\mathrm{n}}+\mathrm{H}_{2}
$$

Preliminary conductivity analysis on these new amide-halide phases proved that the systems with high ionic conductivity show the quickest hydrogen desorption kinetics during heating $[25,29]$. More recently, two new halide-amide phases, $\mathrm{Li}_{7}\left(\mathrm{NH}_{2}\right)_{6} \mathrm{Cl}(\mathrm{SG}=\mathrm{R} 3 . a=9.7367 \AA . . b=8.9307 \AA)$ and $\mathrm{Li}_{6} \mathrm{Mg}_{0.5}\left(\mathrm{NH}_{2}\right)_{6} \mathrm{Cl}$ (SG = R3. $a=9.756 \AA . b=8.9448 \AA$ ) have been synthesized and characterized as potential hydrogen storage materials [30]. Both phases, when heated with $\mathrm{LiH}$ (1:1), released hydrogen at lower temperatures $\left(150^{\circ} \mathrm{C}\right.$ and $\left.200^{\circ} \mathrm{C}\right)$, with no emission of ammonia gas and faster kinetics if compared with the pristine $\mathrm{Li}-\mathrm{N}-\mathrm{H}$ system $\left(220^{\circ} \mathrm{C}\right)$. In addition, rehydrogenation of the dehydrided compounds, in the presence of $\mathrm{LiH}$, is possible under mild conditions of $90 \mathrm{bar} \mathrm{H}_{2}$ at $300{ }^{\circ} \mathrm{C}$.

Furthermore, as highlighted by Chen et al. [31], another important aspect for improving the hydrogen sorption kinetics is related with the sample morphology and desorption conditions. For example, in the $\mathrm{Li}_{2} \mathrm{NH}_{2} \mathrm{Br}$ phase, $\mathrm{LiNH}_{2}$ is confined in the $\mathrm{Br}$ cage resulting in less mobility of $\mathrm{Li}^{+}$ion. For this reason, the desorption of the $\mathrm{Li}_{2} \mathrm{NH}_{2} \mathrm{Br}+\mathrm{LiH}$ system follows the $\mathrm{NH}_{3}$ mediated mechanism although the two components have been intensively ball milled. In other cases, when the $\mathrm{LiNH}_{2}$-type and $\mathrm{LiH}$ phases get an intimate mixture, the migrations of $\mathrm{Li}^{+}$and $\mathrm{H}^{+}$plays a crucial role. Leng et al. [32] showed significant improvements in the desorption properties of the Li-N-H system when mixed with different amounts of $\mathrm{MgCl}_{2}$. From this study emerges that the hydrogen desorption temperatures do not decrease linearly with the increase of $\mathrm{MgCl}_{2}$ amount. Interestingly, for small amount of $\mathrm{MgCl}_{2}$ (1 mol. \%), the main hydrogen desorption temperature is reduced to $267^{\circ} \mathrm{C}$, similar to the $\mathrm{TiCl}_{3}$-doped system $\left(265^{\circ} \mathrm{C}\right)$. Increasing the $\mathrm{MgCl}_{2}$ amount up to $4 \mathrm{~mol}$. $\%$, the formation of a solid solution is observed without any improvement in the desorption temperature, while for content of $\mathrm{MgCl}_{2}$ higher than $25 \mathrm{~mol}$. \%, a reaction with $\mathrm{LiNH}_{2}$ takes place forming $\mathrm{Mg}\left(\mathrm{NH}_{2}\right)_{2}$. Recent works published by Gennari et al. [33,34] introduced $\mathrm{AlCl}_{3}$ as additive and interesting benefits have been reported in terms of ab/desorption rates, cycles stability and hydrogen gravimetric capacity in the Li-N-H system. In a first work [33], it was reported that, for low amount of $\mathrm{AlCl}_{3}, \mathrm{Al}^{3+}$ is incorporated into the $\mathrm{LiNH}_{2}$ structure which can reversible store $4-5 \mathrm{wt}$. \% of $\mathrm{H}_{2}$ at $275{ }^{\circ} \mathrm{C}$. Furthermore, the ammonia gas is completely suppressed during desorption reaction. The system was investigated also for increasing amount of $\mathrm{AlCl}_{3}(0.03,0.08$ and $0.13 \mathrm{~mol})$ [34]. Interestingly, the dehydrogenation rates of the composite milled with $0.08 \mathrm{~mol}$ and $0.13 \mathrm{~mol}$ of $\mathrm{AlCl}_{3}$ are three-fold and six-fold faster, respectively, than the pristine system. In particular, upon $5 \mathrm{~h}$ of intensive ball-milling of the starting materials $\mathrm{LiNH}_{2}, \mathrm{LiH}$ and $(0.13 \mathrm{~mol}) \mathrm{AlCl}_{3}$, a disordered Face Centered Cubic (FCC) solid solution, not yet reported in previous work, is observed. After heating at $300{ }^{\circ} \mathrm{C}$ under hydrogen $(7 \mathrm{bar})$, new trigonal and cubic amide-halide (chloride) phases, isostructural with $\mathrm{Li}_{4}\left(\mathrm{NH}_{2}\right)_{3} \mathrm{Cl}$ [25], are observed. As reported for the previously cited examples, also in the case of the $\mathrm{AlCl}_{3}$-doped $\mathrm{Li}-\mathrm{N}-\mathrm{H}$ system, the improvement of the hydrogen desorption kinetics is accompanied by a significant reduction of the ammonia release. In this specific case, the preparation of the new cubic and trigonal $\mathrm{Li}-\mathrm{Al}-\mathrm{N}-\mathrm{H}-\mathrm{Cl}$ phases consisted in ball milling and thermal treatment performed under different atmospheres (argon and hydrogen) of $\mathrm{LiNH}_{2}$ and $\mathrm{AlCl}_{3}(0.11 \mathrm{~mol})$ [35]. The whole optimized process is resumed in Figure 2. The desorption reaction of the amide-chloride phases depends on the addition of $\mathrm{LiH}$ which completely suppresses the ammonia release and avoids the multi-steps decomposition pathways observed in the post milled $\mathrm{LiNH}_{2}-\mathrm{AlCl}_{3}$ composite. The desorbed product, an imide FCC phase $(a=5.172 \AA)$, is re-hydrogenated under moderate temperatures and represents a reversible system. However, despite the progress made to optimize the whole process, the crystal structure of the two active amide-chloride phases, remains unsolved. 
The performance, in terms of reversibility and maximum desorption temperatures, of the $\mathrm{Li}-\mathrm{Al}-\mathrm{N}-\mathrm{H}-\mathrm{Cl}$ system results comparable and in some case better with respect to the most promising doped $\mathrm{LiNH}_{2}-\mathrm{LiH}$ systems reported in the current literature [18,32,36,37]. For example, after the fourth $\mathrm{ab} /$ des cycle the $\mathrm{AlCl}_{3}$-doped composite is able to desorb roughly $92 \%$ of the theoretical amount of $\mathrm{H}_{2}$, significantly higher than the $67 \%$ reported for the potassium fluoride KF-doped mixture at the same working temperature $\left(300^{\circ} \mathrm{C}\right)[33,36]$. A comparison of the maximum desorption temperatures for different doped systems is reported in Figure 3. As emerged, the dopants show a positive effect reducing the desorption temperatures in the $\mathrm{LiNH}_{2}-\mathrm{LiH}$ system and favoring the release of hydrogen under more moderate conditions. Among them, $\mathrm{AlCl}_{3}$ results to be the most efficient, decreasing the working temperature by $70^{\circ} \mathrm{C}$ with respect to the pristine composite.

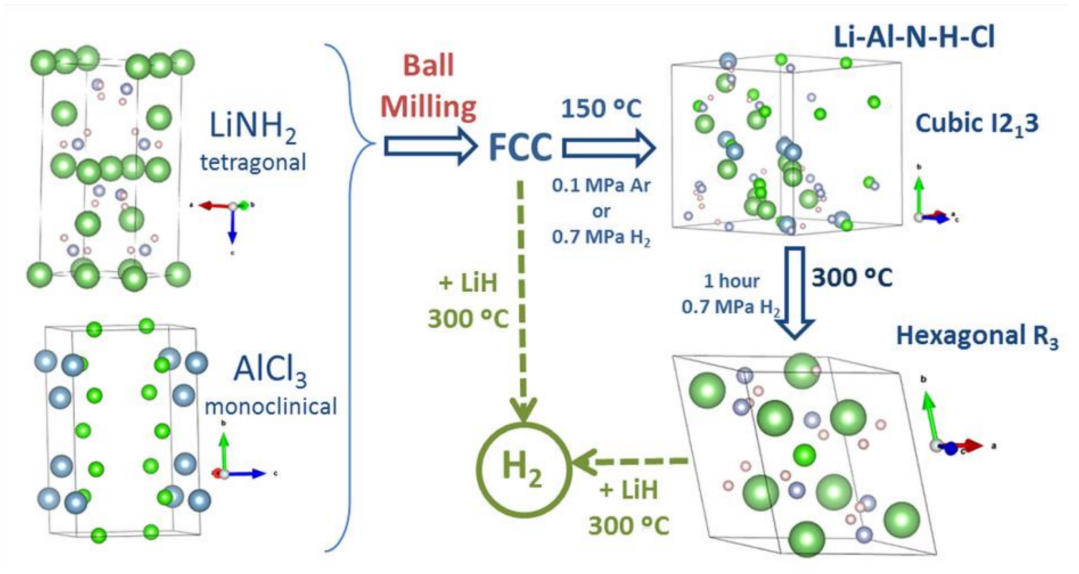

Figure 2. The mechanical treatment of the $\mathrm{LiNH}_{2}-\mathrm{AlCI}_{3}$ mixture lead to the formation of a FCC solid solution which, when thermally treated at $150{ }^{\circ} \mathrm{C}$, forms an amide-chloride phase isostructural with a cubic habit (SG $2_{2} 3$ ). This phase transforms, under $\mathrm{H}_{2}$ pressure, into the trigonal phase (SG R3) after heating at $300{ }^{\circ} \mathrm{C}$. The addition of $\mathrm{LiH}$ to the trigonal phase and FCC solid solution allows to achieve a full and reversible desorption at $300^{\circ} \mathrm{C}$ [35].

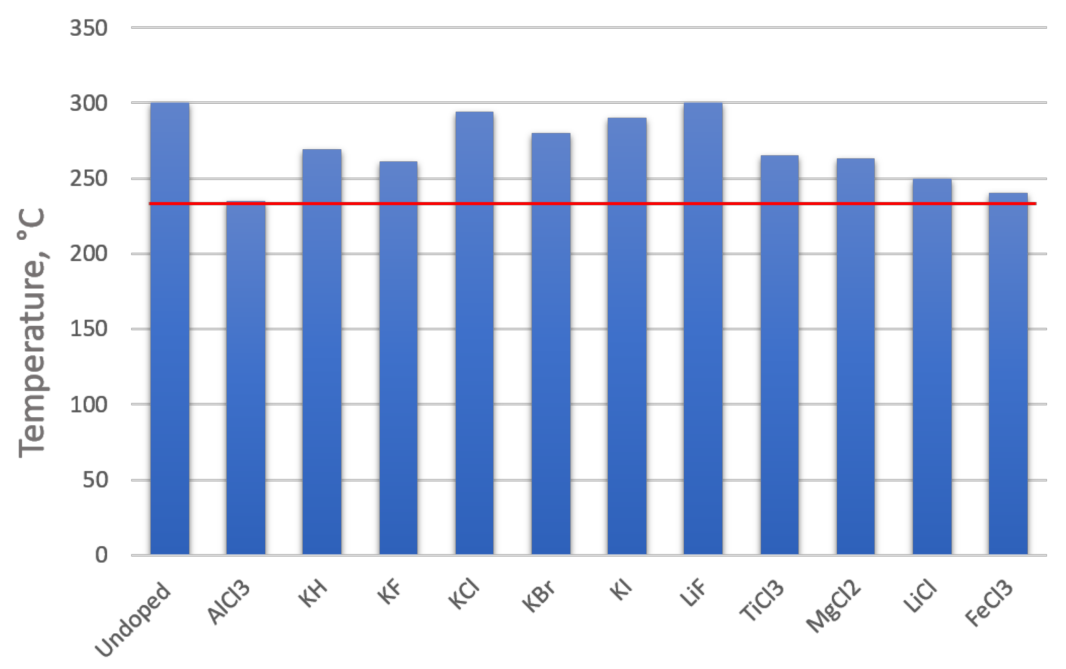

Figure 3. Maximum desorption peak temperatures as a function of different additives on the $\mathrm{LiNH}_{2}-\mathrm{LiH}$ system. The red line is set on the $\mathrm{AlCl}_{3}$ dopant to highlight its performance.

Gennari et al. [38] also tested the contribution of $\mathrm{MgH}_{2}, \mathrm{CaH}_{2}$ and $\mathrm{TiH}_{2}$ in enhancing the kinetic properties of the $\mathrm{LiNH}_{2}-1.6 \mathrm{LiH}$ system. Addition of $\mathrm{TiH}_{2}$ does not show significant improvement, while for the $\mathrm{CaH}_{2}$ - and $\mathrm{MgH}_{2}$-based systems positive effects have been reported. For example, the 
$\mathrm{LiNH}_{2}-1.6 \mathrm{LiH}-0.2 \mathrm{CaH}_{2}$ systems shows a dehydrogenation rate three time faster at $300{ }^{\circ} \mathrm{C}$ than the un-doped materials with about 3.8 wt. \% of $\mathrm{H}_{2}$ stored. Further improvement in terms of working temperature and kinetic rate have been recently reported by Lin and coauthors, by using $\mathrm{CeF}_{4}$ as efficient catalyst for $\mathrm{LiNH}_{2}-\mathrm{LiH}$. This system, when mixed with $10 \mathrm{wt}$. $\%$ of $\mathrm{CeF}_{4}$ can desorb most of its hydrogen content $\left(\sim 5 \mathrm{wt}\right.$. \%) under milder condition $\left(220^{\circ} \mathrm{C}\right)$ compared with the un-doped mixture. $\mathrm{CeF}_{4}$ seems to act as a catalyst reducing the activation energy to $114 \mathrm{~kJ} / \mathrm{mol}$ and suppressing the formation of ammonia gas [39].

The operating temperature of Li-N-H can be reduced by modifying the thermodynamic properties of the system, and, in this context, the substitution of $\mathrm{LiH}$ with other metal hydrides represents one of the strategy widely adopted in the recent past [40-46]. Among the most relevant results, it is worth to highlight that the combination of $\mathrm{LiNH}_{2}$ and $\mathrm{LiBH}_{4}$ (2:1) lead to the desorption of a significant amount of hydrogen, around $10 \mathrm{wt} . \%$, at $350{ }^{\circ} \mathrm{C}$. The decomposition of this binary system passes through the formation of a ternary amide, $\mathrm{Li}_{3} \mathrm{BN}_{2} \mathrm{H}_{8}$, which was the object of an intensive study due to the poor reversibility and kinetics constrains [41,42]. For example, Liu and coauthors reported that the addition of $\mathrm{Co}(\mathrm{OH})_{2}$ to the $2 \mathrm{LiNH}_{2}-\mathrm{LiBH}_{4}$ mixture significantly improved its hydrogen storage properties. At $200{ }^{\circ} \mathrm{C}$ the doped system was able to desorb $9.1 \mathrm{wt}$. \% of hydrogen in only $15 \mathrm{~min}$, while a partial reversibility $\left(1.1 \mathrm{wt}\right.$. \%) was achieved at $350{ }^{\circ} \mathrm{C}$ [45]. The activation energy of the doped system was estimated to be $97 \mathrm{~kJ} / \mathrm{mol}, 25 \%$ lower with respect to the pristine composite $\left(E_{\mathrm{a}}=129 \mathrm{~kJ} / \mathrm{mol}\right)$. Reversibility under milder conditions $\left(200^{\circ} \mathrm{C}\right)$ was achieved when $\mathrm{CaH}_{2}$ is added to $\mathrm{LiNH}_{2}$. However, the recharged amount $\left(2.7 \mathrm{wt} . \% \mathrm{H}_{2}\right)$ and the poor kinetic rate $\left(1.1 \times 10^{-4} \mathrm{wt} . \% / \mathrm{s}\right)$ represent a strong limitation for this binary system [40].

These new and important results have to be considered in order to improve the hydrogen storage properties of the $\mathrm{Li}-\mathrm{N}-\mathrm{H}$ system, at the moment insufficient for any practical application in the field of the on-board technology. In fact, the thermodynamic data reported in literature show that the equilibrium temperature at $\mathrm{H}_{2}$ pressure of $1 \mathrm{bar}$ is higher than $200{ }^{\circ} \mathrm{C}$ for all the systems analyzed up to now. Such high equilibrium temperature sets this system far from the DoE targets for automotive purposes. For these reasons, further efforts have to be addressed to exploit this system in transportation sector and, in this way, understand the local structure, ion mobility and kinetic constrains to dehydrogenation of the intermediate species $\mathrm{Li}_{1+x} \mathrm{NH}_{2-x}$ represent the next challenges in this field [47].

\section{Li-Mg-N-H System}

With respect to the $\mathrm{Li}-\mathrm{N}-\mathrm{H}$ system discussed in the previous section, thermodynamic destabilization can be further achieved by partially replacing $\mathrm{Li}$ with $\mathrm{Mg}$, with a significant reduction of the desorption enthalpy down to ca. $40 \mathrm{~kJ} / \mathrm{mol}$. The reaction between $\mathrm{LiNH}_{2}$ and $\mathrm{MgH}_{2}\left(\right.$ or $\mathrm{Mg}\left(\mathrm{NH}_{2}\right)_{2}$ and $\mathrm{LiH}$ ) for hydrogen storage was reported for the first time in 2004 by five different groups [48-52]. They investigated several factors in the reaction including different ratios between amide and hydride and ab/desorption conditions. Xiong et al. [52] heated lithium amide and magnesium hydride in a 2:1 molar ratio up to $350^{\circ} \mathrm{C}$, and, similar to the Li-N-H system, only hydrogen, without any ammonia, is desorbed. It is found that the hydrogen desorption temperatures are lower than in the $\mathrm{LiNH}_{2}+\mathrm{LiH}$ system. From ex-situ powder X-ray Diffraction (XRD) performed on the sample upon heating, new peaks are observed. This new sequence of Bragg reflections does not match with any of the previously identified in the Li-N-H compounds, and it is finally associated with the $\mathrm{Li}_{2} \mathrm{MgN}_{2} \mathrm{H}_{2}$ phase. This ternary imide crystallizes with a cubic lattice $(a=10.035 \AA)$ and its formation is summarized in the following reaction:

$$
2 \mathrm{LiNH}_{2}+\mathrm{MgH}_{2} \rightarrow \mathrm{Li}_{2} \mathrm{Mg}(\mathrm{NH})_{2}+2 \mathrm{H}_{2}
$$


The solid product of Equation (4) can be re-hydrogenated under 90 bar of $\mathrm{H}_{2}$ pressure at $180{ }^{\circ} \mathrm{C}$. Upon cycling of the ternary imide, the XRD pattern showed that the products are represented by $\mathrm{Mg}\left(\mathrm{NH}_{2}\right)_{2}$ and $\mathrm{LiH}$ rather than the original starting materials $\mathrm{LiNH}_{2}$ and $\mathrm{MgH}_{2}$ (Equation (5)):

$$
2 \mathrm{LiNH}_{2}+\mathrm{MgH}_{2} \rightarrow \mathrm{Li}_{2} \mathrm{Mg}(\mathrm{NH})_{2}+2 \mathrm{H}_{2} \leftrightarrow \mathrm{Mg}\left(\mathrm{NH}_{2}\right)_{2}+2 \mathrm{LiH}
$$

At the same time, Luo [51] also published further work where the absorption and desorption steps of the $2 \mathrm{LiNH}_{2}+\mathrm{MgH}_{2}$ and $\mathrm{LiNH}_{2}+\mathrm{LiH}$ systems are compared. The $\mathrm{Li}-\mathrm{Mg}-\mathrm{N}-\mathrm{H}$ system starts to desorb hydrogen at lower temperature $\left(100{ }^{\circ} \mathrm{C}\right)$ with respect to the $\mathrm{Li}-\mathrm{N}-\mathrm{H}$ system. Important differences also emerge in the P-C-T curves: the Li-Mg-N-H composite shows a hydrogen equilibrium pressure of 50 bar at $220{ }^{\circ} \mathrm{C}$ against the 1 bar of $\mathrm{H}_{2}$ at $280{ }^{\circ} \mathrm{C}$ reported for the $\mathrm{Li}-\mathrm{N}-\mathrm{H}$ mixture. Furthermore, the Li-Mg-N-H sample can be cycled 9 times with no degradation in desorption capacity. Chen et al. [53] investigated in detail the first 4 cycles of the ball-milled $2 \mathrm{LiNH}_{2}+\mathrm{MgH}_{2}$ system. In the first dehydrogenation cycle, the desorption rate is significantly slower than the subsequent three runs, ascribable to the fact that, in the first one, there is an interaction between the $\mathrm{LiNH}_{2}$ and $\mathrm{MgH}_{2}$. The sorption mechanism, summarized in Figure 4, has been further investigated by Sickafoose et al. [54] In the first step of the isotherm, one hydrogen atom is inserted into the $\mathrm{Li}_{2} \mathrm{MgN}_{2} \mathrm{H}_{2}$ phase, forming $\mathrm{Li}_{2} \mathrm{MgN}_{2} \mathrm{H}_{3}$. The other hydrogen atoms react with $\mathrm{Li}_{2} \mathrm{MgN}_{2} \mathrm{H}_{3}$ in a second step to produce the new species $\mathrm{LiH}$ and $\mathrm{Mg}\left(\mathrm{NH}_{2}\right)_{2}$.

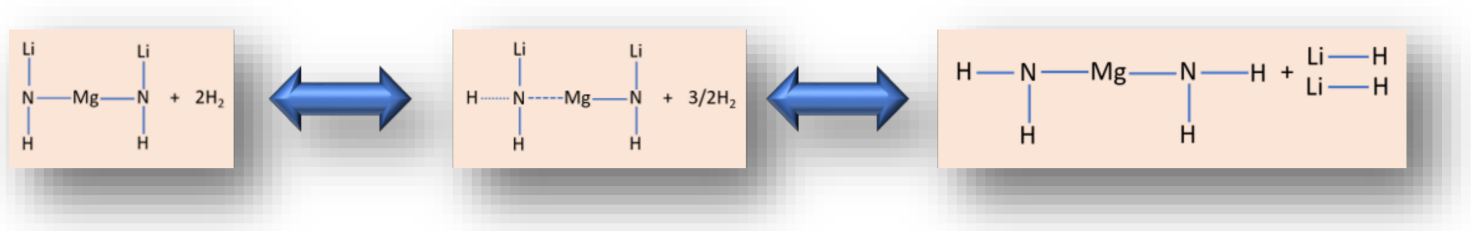

Figure 4. Proposed mechanism in the hydrogen sorption reaction of the $\mathrm{Li}_{2} \mathrm{Mg}(\mathrm{NH})_{2}$ system [54].

Luo et al. $[55,56]$ determined the $\mathrm{NH}_{3}$ emission in the desorption step of the $2 \mathrm{LiNH}_{2}+\mathrm{MgH}_{2}$ system. The results indicate that the $\mathrm{NH}_{3}$ concentration is around $180 \mathrm{ppm}$ at $180^{\circ} \mathrm{C}$ and $720 \mathrm{ppm}$ at $240{ }^{\circ} \mathrm{C}$, restricting the cycling and then the applicability. Markmaitree et al. [57] compared the reaction kinetics and the $\mathrm{NH}_{3}$ emission of the $2 \mathrm{LiNH}_{2}+\mathrm{MgH}_{2}$ and $\mathrm{LiNH}_{2}+\mathrm{LiH}$ systems. The $2 \mathrm{LiNH}_{2}+$ $\mathrm{MgH}_{2}$ mixture seems to possess a higher activation energy and $\mathrm{NH}_{3}$ emission than the $\mathrm{LiNH}_{2}+\mathrm{LiH}$ mixture. In addition, the samples ball milled for longer time present reduced amount of $\mathrm{NH}_{3}$ released during the desorption step. This aspect can be explained taking into account the smaller particle size and larger surface area of the produced $\mathrm{MgH}_{2}$, which favor the interaction with $\mathrm{NH}_{3}$. When the system is heated up to $210{ }^{\circ} \mathrm{C}$ for $5 \mathrm{~h}, \mathrm{MgNH}, \mathrm{Li}_{2} \mathrm{Mg}(\mathrm{NH})_{2}$ phases and residual $\mathrm{LiNH}_{2}$ and $\mathrm{MgH}_{2}$ are present in final mixture. On the other hand, after heating for $10 \mathrm{~h}, \mathrm{LiNH}_{2}$ and $\mathrm{MgNH}$ are completely disappeared, while a small amount of $\mathrm{MgH}_{2}$ is detected. The main phase is represented by the ternary imide $\mathrm{Li}_{2} \mathrm{Mg}(\mathrm{NH})_{2}$ which suggests that the reaction mechanism involves the decomposition of lithium amide to imide and $\mathrm{NH}_{3}$ followed by the reaction of $\mathrm{MgH}_{2}$ with $\mathrm{NH}_{3}$ as reported in Equation (6):

$$
\mathrm{MgH}_{2}+2 \mathrm{NH}_{3} \rightarrow \mathrm{Mg}\left(\mathrm{NH}_{2}\right)_{2}+2 \mathrm{H}_{2} .
$$

The reaction between $\mathrm{MgH}_{2}$ and $\mathrm{NH}_{3}$ takes place with a low rate [58]. The magnesium amide forms and then decomposes to $\mathrm{MgNH}$ at a reasonable rate from $250{ }^{\circ} \mathrm{C}$ with the release of $\mathrm{NH}_{3}$ [57]. Further ammonia is produced in the last step, then reacts with residual $\mathrm{MgH}_{2}$ and the reaction cycle continues. The products from this cycle are $\mathrm{MgNH}$ and $\mathrm{Li}_{2} \mathrm{NH}$ which could react to form $\mathrm{Li}_{2} \mathrm{Mg}(\mathrm{NH})_{2}$ as suggested in Equation (7):

$$
\mathrm{MgNH}+\mathrm{Li}_{2} \mathrm{NH} \rightarrow \mathrm{Li}_{2} \mathrm{Mg}(\mathrm{NH})_{2}
$$


However, XRD analysis does not support evidence of $\mathrm{Mg}\left(\mathrm{NH}_{2}\right)_{2}$ in any step, probably because the reaction reported in Equation (6) proceeds with a slow rate. Furthermore, $\mathrm{Mg}\left(\mathrm{NH}_{2}\right)_{2}$ could not be observed by FTIR because of its amorphous nature upon ball milling [59].

Rijssenbeek et al. [60] investigated the hydrogen sorption path of the $2 \mathrm{LiNH}_{2}+\mathrm{MgH}_{2}$ mixture by in situ X-ray diffraction and neutron diffraction. These studies confirm that the dehydrogenated product is a ternary lithium-magnesium imide, $\mathrm{Li}_{2} \mathrm{Mg}(\mathrm{NH})_{2}$, which undergoes two structural transitions from an orthorhombic structure to a primitive cubic structure $\left(\beta-\mathrm{Li} \mathrm{i}_{2} \mathrm{Mg}(\mathrm{NH})_{2}\right)$ at intermediate temperature $\left(350{ }^{\circ} \mathrm{C}\right)$ followed by a face-centered cubic crystal structure $\left(\gamma-\mathrm{Li}{ }_{2} \mathrm{Mg}(\mathrm{NH})_{2}\right)$ at high temperature $\left(500^{\circ} \mathrm{C}\right)$. Complete hydrogen absorption is observed for $\alpha-\mathrm{Li}_{2} \mathrm{Mg}(\mathrm{NH})_{2}$ with the formation of $\mathrm{Mg}\left(\mathrm{NH}_{2}\right)_{2}$ and $\mathrm{LiH}$. During the dehydrogenation phases of the cycling process, $\mathrm{NH}_{3}$ is still detected, although in lower amount than the first desorption. It is important to highlight that using $\mathrm{Mg}\left(\mathrm{NH}_{2}\right)_{2}$ and $\mathrm{LiH}$ as starting materials, the three phases of $\mathrm{Li}_{2} \mathrm{Mg}(\mathrm{NH})_{2}$ can be formed, although $\alpha-\mathrm{Li}_{2} \mathrm{Mg}(\mathrm{NH})_{2}$ is difficult to detect and the $\beta-\mathrm{Li}_{2} \mathrm{Mg}(\mathrm{NH})_{2}$ phase appears at a lower temperature.

Concerning the experimental thermodynamic properties, Yang et al. [61] estimated a value of $\Delta \mathrm{H}=41.6 \mathrm{~kJ} / \mathrm{mol}$, close to that expected by theoretical calculations [50]. However, although the temperature of hydrogen release is approaching $90^{\circ} \mathrm{C}$, the reaction is kinetically limited. Therefore, to improve the kinetics at temperatures lower than $200^{\circ} \mathrm{C}$, the reaction needed to be catalyzed with suitable dopants or additives. During the last years, many attempts have been made to improve the sorption kinetics of the $2 \mathrm{LiNH}_{2}+\mathrm{MgH}_{2}$ system and, in this context, a large number of papers have been published [62-74]. Luo et al. reported faster absorption kinetics by doping with less than 4 mol. \% of $\mathrm{KH}$. In these experiments, the difference in the absorption rates of the doped and undoped systems is particularly noticeable at $180^{\circ} \mathrm{C}$ and 115 bar, while it becomes less pronounced at higher temperature and pressure (i.e., $200^{\circ} \mathrm{C}$ and 155 bar, respectively) [73]. The studies conducted separately by Yang [75] and Sudik [76] proved that the addition in stoichiometric amount of $\mathrm{LiBH}_{4}$ has a significant impact on the hydrogen storage properties of the Li-Mg-N-H system. Ulmer et al. [71] verified that co-doping with $\mathrm{LiBH}_{4}$ and $\mathrm{KH}$ can significantly improve the de/absorption kinetics of the $2 \mathrm{LiNH}_{2}+\mathrm{MgH}_{2}$ system. Interestingly, co-doping with $\mathrm{LiBH}_{4}$ and $\mathrm{ZrCoH}_{3}$ is even more effective: a mixture with composition $2 \mathrm{LiNH}_{2}+1.1 \mathrm{MgH}_{2}-\left(0.1 \mathrm{LiBH}_{4}+3\right.$ mass $\left.\% \mathrm{ZrCoH}_{3}\right)$ desorbs 3.2 wt. \% under 1 bar $\mathrm{H}_{2}$ at $180{ }^{\circ} \mathrm{C}$ within $100 \mathrm{~min}$ and can be re-hydrogenated in only $7 \mathrm{~min}$. The study also demonstrates that this system can be processed efficiently in batches up to $200 \mathrm{~g}$ (vibrational mill) and utilized in a tank prototype, showing similar performance to the material processed at lab-scale (planetary mill) [71].

More recently, Goudy et al. [65] showed that $\mathrm{RbH}$ added in catalytic amount is significantly better than $\mathrm{KH}$ for enhancing the hydrogen sorption properties of the $2 \mathrm{LiNH}_{2}+\mathrm{MgH}_{2}$ system, while the desorption temperature remains almost the same for both dopants. The kinetic findings prove that the $\mathrm{RbH}$-doped system releases hydrogen two and 60 times faster than $\mathrm{KH}$-doped and undoped systems, respectively. In another study, the same authors determine that the desorption rates of the $\mathrm{K}-, \mathrm{Rb}$ - and Cs-doped $2 \mathrm{LiNH}_{2}+\mathrm{MgH}_{2}$ system increase in the order: undoped $<\mathrm{CsH}<\mathrm{KH}<\mathrm{RbH}$. Modeling of the kinetic data using a shrinking-core model suggests that the desorption process is diffusion controlled in the first stage of the reaction [66].

To better increase the kinetic reaction and suppress $\mathrm{NH}_{3}$ emission in efficient manner, Demirocak et al. [64] doped the Li-Mg-N-H mixture with single-walled carbon nanotubes SWCNT $/ 20 \%$ Ru catalyst, obtaining an effective elimination of the ammonia gas. Anderson et al. [63], demonstrated that addition of halides $\left(\mathrm{CaCl}_{2}\right.$ and $\left.\mathrm{CaBr}_{2}\right)$ on the $\mathrm{Li}-\mathrm{Mg}-\mathrm{N}-\mathrm{H}$ system can improve the desorption kinetics. In particular, these halides seem to favor the metathesis reaction already during the milling. The lowest dehydrogenation onset temperatures $\left(<100^{\circ} \mathrm{C}\right)$ are achieved in the $2 \mathrm{LiNH}_{2}-\mathrm{MgH}_{2}-0.15 \mathrm{CaX}\left(\mathrm{X}=\mathrm{Cl}_{2}\right.$ and $\left.\mathrm{Br}_{2}\right)$ system. In particular the $\mathrm{CaBr}_{2}$-doped system presents the lowest desorption onset and peak temperatures $\left(80^{\circ} \mathrm{C}\right.$ and $135{ }^{\circ} \mathrm{C}$, respectively) and an activation energy of $78.8 \mathrm{~kJ} / \mathrm{mol}$. Combined effect of ball milling and molar ratio $\mathrm{LiNH}_{2}: \mathrm{MgH}_{2}$ on the sorption and structural process were studied by Varin et al. [77,78]. The $\mathrm{LiNH}_{2}+\mathrm{nMgH}_{2}(\mathrm{n}=0.55,0.6$ and 0.7 ) system is partially converted, by a metathesis reaction promoted by high-energy ball 
milling, into $\mathrm{Mg}\left(\mathrm{NH}_{2}\right)_{2}$ and $\mathrm{LiH}$. The apparent activation energy of $71.7 \mathrm{~kJ} / \mathrm{mol}$ is observed for the $\mathrm{LiNH}_{2}+0.7 \mathrm{MgH}_{2}$ system milled for $25 \mathrm{~h}$, while a further decrease down to $65.0 \mathrm{~kJ} / \mathrm{mol}$ is obtained when catalyzed by n-Ni composite. The Van't Hoff analysis shows that the equilibrium temperature at 1 bar $\mathrm{H}_{2}$ is $70.1^{\circ} \mathrm{C}$ for this mixture. Additionally, the $\mathrm{LiNH}_{2}+0.7 \mathrm{MgH}_{2}$ mixture is fully reversible and desorbs/absorbs 3.6 wt. $\% \mathrm{H}_{2}$ at $175^{\circ} \mathrm{C}$.

A mixture of $\mathrm{Mg}\left(\mathrm{NH}_{2}\right)_{2}$ and $\mathrm{LiH}$ is regarded as an equivalent of the $2 \mathrm{LiNH}_{2}+\mathrm{MgH}_{2}$ system because of the metathesis reaction between the two hydrides-amides pairs:

$$
2 \mathrm{LiNH}_{2}+\mathrm{MgH}_{2} \rightarrow \mathrm{Mg}\left(\mathrm{NH}_{2}\right)_{2}+2 \mathrm{LiH} .
$$

The $\mathrm{Mg}\left(\mathrm{NH}_{2}\right)_{2}+2 \mathrm{LiH}$ system presents some advantages compared to the $2 \mathrm{LiNH}_{2}+\mathrm{MgH}_{2}$ composite. For example, as well explained in the previous section, after a cycle of hydrogen desorption/absorption, the $2 \mathrm{LiNH}_{2}+\mathrm{MgH}_{2}$ mixture becomes a $\mathrm{Mg}\left(\mathrm{NH}_{2}\right)_{2}+2 \mathrm{LiH}$ system. Considering that this step is accompanied by release of ammonia and kinetic constraints, starting from the $\mathrm{Mg}\left(\mathrm{NH}_{2}\right)_{2}+2 \mathrm{LiH}$ system is more advisable. One of the first studies on $\mathrm{Mg}\left(\mathrm{NH}_{2}\right)_{2}+2 \mathrm{LiH}$ was reported by Xiong et al. [79] in 2005. The reactants, ball-milled together for $48 \mathrm{~h}$, upon dehydrogenation at $250{ }^{\circ} \mathrm{C}$ release a considerable amount of hydrogen (5.0 wt. \%) with the formation of the $\mathrm{Li}_{2} \mathrm{Mg}(\mathrm{NH})_{2}$ phase. The system presents a very appealing reaction enthalpy of $38.9 \mathrm{~kJ} / \mathrm{mol} \mathrm{H}_{2}$, but, on the other hand, the activation energy estimated is relatively high $\left(E_{a}=102 \mathrm{~kJ} / \mathrm{mol}\right)$. Xiong et al. concluded that to decrease the activation energy of this system it is necessary to favor the interaction between $\mathrm{H}^{+}$and $\mathrm{H}^{-}$of the amide and hydride, respectively, or to weaken the Li-N and N-H bonds. Xiong et al. [80] also investigated the effect of molar ratios of $\mathrm{Mg}\left(\mathrm{NH}_{2}\right)_{2}$ and $\mathrm{LiH}$, on the desorption properties. The 1:2 mixture presents remarkable differences and better desorption properties with respect to the 1:1 or 1:3 ratios. Furthermore, lower content of $\mathrm{LiH}$ favors the desorption of $\mathrm{NH}_{3}$. These results were also confirmed by other works [81-84]. For example, Hu et al. [82], highlighted that for lower content of $\mathrm{LiH}$, severe ammonia release should be expected, while an excess of $\mathrm{LiH}$ affects, in negative, the gravimetric capacity of the system. Liu et al. [85] investigated the effect of sodium compounds on the $\mathrm{Li}-\mathrm{Mg}-\mathrm{N}-\mathrm{H}$ system. The hydrogen desorption kinetics of the Na-containing systems are significantly improved and $\mathrm{NH}_{3}$ emission reduced. The activation energies of the three samples, $\mathrm{Mg}\left(\mathrm{NH}_{2}\right)_{2}+2 \mathrm{LiH}$, $\mathrm{Mg}\left(\mathrm{NH}_{2}\right)_{2}+1.6 \mathrm{LiH}+0.4 \mathrm{NaH}$ and $0.8 \mathrm{Mg}\left(\mathrm{NH}_{2}\right)_{2}+0.4 \mathrm{NaNH}_{2}+2 \mathrm{LiH}$, are 105.5, 97.7 , and $92.5 \mathrm{~kJ} / \mathrm{mol}$, respectively. In spite of lower activation energies, the sodium-containing systems possess, as expected, decreased hydrogen gravimetric capacities with respect to the un-doped material. Sudik et al. [86], instead, investigated the effect of $\mathrm{Li}_{2} \mathrm{Mg}(\mathrm{NH})_{2}$ (5 wt. \%, $10 \mathrm{wt}$. \% and $15 \mathrm{wt}$. \%) on the sorption properties of the $\mathrm{Mg}\left(\mathrm{NH}_{2}\right)_{2}+2 \mathrm{LiH}$ systems. The system milled with 10 wt. $\% \mathrm{Li}_{2} \mathrm{Mg}(\mathrm{NH})_{2}$ desorbs hydrogen at a $40{ }^{\circ} \mathrm{C}$ lower temperature. The desorption curves reveal a two-step hydrogen release as for the un-doped material. Additionally, the activation energy of the $\mathrm{Li}_{2} \mathrm{Mg}(\mathrm{NH})_{2}$-coontaining sample is lowered by $13 \%$ from $88.0 \mathrm{~kJ} / \mathrm{mol}$ to $76.2 \mathrm{~kJ} / \mathrm{mol}$. Liu et al. [87] synthesized $\mathrm{Li}_{2} \mathrm{MgN}_{2} \mathrm{H}_{2}$ by annealing a mixture of $\mathrm{Mg}\left(\mathrm{NH}_{2}\right)_{2}-2 \mathrm{LiNH}_{2}$ and investigated its size-dependent hydrogen storage performance. Markedly enhanced kinetics of hydrogen absorption/desorption are achieved with a reduction in the particle and grain size. Janot et al. [88] compared the hydrogen storage performance of the two reactions $\mathrm{Mg}\left(\mathrm{NH}_{2}\right)_{2}+2 \mathrm{LiH}$ and $2 \mathrm{LiNH}_{2}+\mathrm{MgH}_{2}$. For the $1: 2 \mathrm{MgH}_{2}-\mathrm{LiNH}_{2}$ system, it evolved ammonia under dynamic vacuum while the ball-milled 1:2 $\mathrm{Mg}\left(\mathrm{NH}_{2}\right)_{2}-\mathrm{LiH}$ mixture desorbs $5.0 \mathrm{wt}$ \% of hydrogen in $25 \mathrm{~min}$ at $220^{\circ} \mathrm{C}$ and it can be cycled at $200^{\circ} \mathrm{C}$ with a total capacity around $4.8 \mathrm{wt} . \%$. Further efforts have been devoted to the kinetic improvement of the $\mathrm{Mg}\left(\mathrm{NH}_{2}\right)_{2}+2 \mathrm{LiH}$ system by using catalysts or additives [89-94]. Wang et al. [91] proposed graphite-supported Ru nanoparticles as efficient additive in the $\mathrm{Mg}\left(\mathrm{NH}_{2}\right)_{2}+2 \mathrm{LiH}$ system: after mixing, a considerable enhancement in the ab/dehydrogenation kinetics for more than 10 cycles have been observed. Srivastva et al. [92] proved that the addition of vanadium-based catalysts can catalyze efficiently the desorption reaction of the $\mathrm{Li}-\mathrm{Mg}-\mathrm{N}-\mathrm{H}$ system. In particular, the sample mixed with $\mathrm{VCl}_{3}$ presents a hydrogen desorption temperature lower than the pristine material. This mixture starts to release hydrogen at $50{ }^{\circ} \mathrm{C}$ ad its desorption rate is enhanced up to $38 \%$. Similar performance has been obtained in the $\mathrm{Mg}\left(\mathrm{NH}_{2}\right)+2 \mathrm{LH}$ 
catalyzed by $\mathrm{CaH}_{2}$. The desorption starts at temperature of $78^{\circ} \mathrm{C}$ and the activation energy estimated for the first dehydrogenation step decreases from a value of $133.8 \pm 4.1 \mathrm{~kJ} / \mathrm{mol}$ in the pristine material to $105.1 \pm 3.2 \mathrm{~kJ} / \mathrm{mol}$ when $\mathrm{CaH}_{2}$ is added [95].

Significant improvements, in terms of sorption properties and ammonia suppression were achieved by Chen et al. in 2008, either adding $\mathrm{LiBH}_{4}$ or by partially replacing $\mathrm{LiH}$ with $\mathrm{KH}[93,96]$. The composite $\mathrm{Mg}\left(\mathrm{NH}_{2}\right)_{2}+2 \mathrm{LiH}+0.1 \mathrm{LiBH}_{4}$ can desorb and fully re-absorb $5 \mathrm{wt}$. \% of $\mathrm{H}_{2}$ at temperatures of $140{ }^{\circ} \mathrm{C}$ and $100{ }^{\circ} \mathrm{C}$ respectively, with a rate three times faster than the undoped material. The system $\mathrm{Mg}\left(\mathrm{NH}_{2}\right)_{2}+1.9 \mathrm{LiH}+0.1 \mathrm{KH}$ starts to release hydrogen at temperatures as low as $80^{\circ} \mathrm{C}$. Moreover, complete absorption and desorption can be carried out in equilibrium conditions (Pressure-Composition-Isotherm (PCI) measurements) at $107^{\circ} \mathrm{C}$, revealing a $\mathrm{H}_{2}$ pressure of 2.5 bar. The hydrogenation can be performed to a considerable extent (ca. 75\%) in just 12 min with a hydrogen pressure of $30 \mathrm{bar}$ and a temperature equal to $143^{\circ} \mathrm{C}$ : a real breakthrough, considering that for the undoped system $20 \mathrm{~h}$ are necessary in order to absorb the same amount of hydrogen. Moreover, differently from the undoped sample, in the $\mathrm{KH}$-containing system the ammonia released was almost undetectable below $200^{\circ} \mathrm{C}$. Several studies tried to identify and characterize the bimetallic intermediates that can be formed from the interaction of $\mathrm{KH}$ and $\mathrm{Mg}\left(\mathrm{NH}_{2}\right)_{2}$ [97-101]. Interesting results, in terms of hydrogen sorption kinetics, can be achieved using different $\mathrm{K}$-sources, such as $\mathrm{KF}$ and $\mathrm{KOH}$, however, the active species seems to be always $\mathrm{KH}$ [102-106]. Comparable performance was obtained also with the use of RbF: this was mainly ascribable to the similar structures of $\mathrm{KMgNH}_{2} \mathrm{NH}$ and $\mathrm{RbMgNH}_{2} \mathrm{NH}$ formed during the dehydrogenation step $[107,108]$. Interestingly, the addition of both $\mathrm{KH}$ and $\mathrm{RbH}$ is a simple but effective strategy to further enhance the sorption rate and reversibility of the system [89]. The nominal $\mathrm{Mg}\left(\mathrm{NH}_{2}\right)_{2}+2 \mathrm{LiH}+0.04 \mathrm{KH}+0.04 \mathrm{RbH}$ system is able to store $5.2 \mathrm{wt}$ \% of hydrogen reversibly at $130{ }^{\circ} \mathrm{C}$ (dehydrogenation) $-120{ }^{\circ} \mathrm{C}$ (hydrogenation) with a very fast kinetic ( $43^{\prime}$ times faster than pristine material). Furthermore, a noticeable cycling performance has been reported: around of $93 \%$ of hydrogen storage capacity remains after more than 50 cycles. Also worth mentioning are the results obtained by using $\mathrm{CsH}$ in place of $\mathrm{RbH}$, as single dopant [109] or as co-dopant (with $\mathrm{KH})$ [110] in the $\mathrm{Mg}\left(\mathrm{NH}_{2}\right)_{2}-2 \mathrm{LiH}$ system.

In a very recent work, Guo et al. synthesized uniform $\mathrm{Li}_{2} \mathrm{Mg}(\mathrm{NH})_{2}$ nanoparticles embedded into carbon nanofibers, which can ab/desorb efficiently (50 cycles) $2 \mathrm{wt}$. \% of hydrogen at $130{ }^{\circ} \mathrm{C}$. This high performing system exhibits an enthalpy of dehydrogenation of $35.7 \mathrm{~kJ} / \mathrm{mol} \mathrm{H}_{2}$, slightly lower if compared with that observed in the bulk system $\left(44.1 \mathrm{~kJ} / \mathrm{mol} \mathrm{H}_{2}\right)$. This thermodynamic destabilization was ascribed to both the interaction between the $\mathrm{Li}_{2} \mathrm{Mg}(\mathrm{NH})_{2}$ compound and the carbon matrix and the reduction of the particle size to nanometer scale [111].

\section{Li-Mg-N-H-Borohydride Systems}

Recently, the Li-Mg-N-H-borohydride system has attracted increasing interest. In fact, the use of borohydrides as additives alters not only the kinetics but also the thermodynamics of $\mathrm{Li}-\mathrm{Mg}-\mathrm{N}-\mathrm{H}$ system. Inspired by the richness of the chemistry observed in the binary systems $2 \mathrm{LiBH}_{4}+\mathrm{MgH}_{2}$ [112], $2 \mathrm{LiNH}_{2}+\mathrm{LiBH}_{4}[41,113]$ and $2 \mathrm{LiNH}_{2}+\mathrm{MgH}_{2}$ [51,52], a ternary mixture of $2 \mathrm{LiNH}_{2}+\mathrm{MgH}_{2}+$ $\mathrm{LiBH}_{4}$ was investigated by Yang et al. in 2007 [75]. In their following works [114,115], an optimum composition of this ternary system was found to be $6 \mathrm{LiNH}_{2}+3 \mathrm{MgH}_{2}+\mathrm{LiBH}_{4}$ by combinatorial synthesis and screening techniques. A self-catalyzed reaction mechanism for this ternary composition was proposed: (1) during milling $\mathrm{LiNH}_{2}$ reacts with $\mathrm{LiBH}_{4}$ to form $\mathrm{Li}_{4} \mathrm{BN}_{3} \mathrm{H}_{10}$ (Equation (9)); (2) $\mathrm{Li}_{4} \mathrm{BN}_{3} \mathrm{H}_{10}$ interacts with $\mathrm{MgH}_{2}$ producing $\mathrm{Li}_{2} \mathrm{Mg}(\mathrm{NH})_{2}$ (Equation (10)); (3) the formed $\mathrm{Li}_{2} \mathrm{Mg}(\mathrm{NH})_{2}$ functions as seeds for the reaction reported in Equation (5) leading to a general improvement of the hydrogen storage properties [116]. The beneficial effect of "seeding" in improving the dehydrogenation kinetics of Equation (5) has been confirmed by the same group [86]. The drawback of this ternary 
system is that the reversible $\mathrm{H}_{2}$ capacity is a little lower than that of the pristine system. In fact, the maximum reversible $\mathrm{H}_{2}$ content for the optimum composition is only $3.5 \mathrm{wt}$. \%:

$$
\begin{gathered}
3 \mathrm{LiNH}_{2}+\mathrm{LiBH}_{4} \rightarrow \mathrm{Li}_{4}\left(\mathrm{BH}_{4}\right)\left(\mathrm{NH}_{2}\right)_{3} \\
2 \mathrm{Li}_{4}\left(\mathrm{BH}_{4}\right)\left(\mathrm{NH}_{2}\right)_{3}+3 \mathrm{MgH}_{2} \rightarrow 3 \mathrm{Li}_{2} \mathrm{Mg}(\mathrm{NH})_{2}+2 \mathrm{LiBH}_{4}+6 \mathrm{H}_{2}
\end{gathered}
$$

The conversion of $\mathrm{LiNH}_{2}$ and $\mathrm{MgH}_{2}$ into $\mathrm{Mg}\left(\mathrm{NH}_{2}\right)_{2}$ and $\mathrm{LiH}$ may occur during the dehydrogenation process (Equation (5)). Hu et al. [117], compared the dehydrogenation performance, thermal effects and chemical changes of $1 \mathrm{Mg}\left(\mathrm{NH}_{2}\right)_{2}+2 \mathrm{LiH}+1 \mathrm{LiBH}_{4}$ and $2 \mathrm{LiNH}_{2}+\mathrm{MgH}_{2}+\mathrm{LiBH}_{4}$. This investigation showed that $\mathrm{MgH}_{2}$ and $\mathrm{LiNH}_{2}$ converts to $\mathrm{Mg}\left(\mathrm{NH}_{2}\right)_{2}$ and $\mathrm{LiH}$ at $120{ }^{\circ} \mathrm{C}$ in the presence of $\mathrm{LiBH}_{4}$. Similar results can also be found by changing the ratios of $\mathrm{MgH}_{2}$ in the $2 \mathrm{LiNH}_{2}+$ $\mathrm{LiBH}_{4}+\mathrm{x}\left(\mathrm{MgH}_{2}\right)$ system. During ball milling, $\mathrm{MgH}_{2}$ reacts with $\mathrm{LiNH}_{2}$ to form $\mathrm{Mg}\left(\mathrm{NH}_{2}\right)_{2}$ and $\mathrm{LiH}$ together with $\mathrm{Li}_{4}\left(\mathrm{BH}_{4}\right)\left(\mathrm{NH}_{2}\right)_{3}$, as reported by Equation (9) [76].

Following these works, $\mathrm{Hu}$ et al. [96], introduced $\mathrm{LiBH}_{4}$ as an additive for $\mathrm{Mg}\left(\mathrm{NH}_{2}\right)_{2}+2 \mathrm{LiH}$ system. $\mathrm{Mg}\left(\mathrm{NH}_{2}\right)_{2}+2 \mathrm{LiH}+0.1 \mathrm{LiBH}_{4}$ shifts its hydrogen desorption onset and maximum peak to lower temperatures, and more than $5 \mathrm{wt}$. \% of $\mathrm{H}_{2}$ can be reversibly released and stored at 140 and $100{ }^{\circ} \mathrm{C}$, respectively. Furthermore, its theoretical dehydrogenation temperature is $70{ }^{\circ} \mathrm{C}$ at 1 bar of hydrogen pressure, which is about $20^{\circ} \mathrm{C}$ lower than the pristine system. There are three main reasons for the achieved improvement. Firstly, $\mathrm{LiBH}_{4}$ facilitates the recrystallization of $\mathrm{Mg}\left(\mathrm{NH}_{2}\right)_{2}$ after milling, the as formed $\mathrm{N}$-atom matrix in the crystalline of $\mathrm{Mg}\left(\mathrm{NH}_{2}\right)_{2}$ shares a similar sublattice structure with the desorption product $\mathrm{Li}_{2} \mathrm{Mg}(\mathrm{NH})_{2}$, similar to the "seeding" effect reported by Yang et al. [86] thus leading to an improvement of dehydrogenation kinetics [118]. Secondly, $\mathrm{Li}_{4}\left(\mathrm{BH}_{4}\right)\left(\mathrm{NH}_{2}\right)_{3}$ possess a high $\mathrm{Li}+$ ion conductivity and low melting temperature, which increase the transportation of mass and enlarge the contact between reactants. In addition, being this phase cyclically formed and consumed during the dehydrogenation step, it participates in the capture and release of $\mathrm{LiNH}_{2}$, one dehydrogenation product of $\mathrm{Mg}\left(\mathrm{NH}_{2}\right)_{2}+2 \mathrm{LiH}$. Thirdly, $\mathrm{LiBH}_{4}$ alters not only the kinetics but also the thermodynamics of $\mathrm{Mg}\left(\mathrm{NH}_{2}\right)_{2}+2 \mathrm{LiH}[96,118]$. Varying the molar ratio of $\mathrm{Mg}\left(\mathrm{NH}_{2}\right)_{2}, \mathrm{LiH}$ and $\mathrm{LiBH}_{4}$, the optimum molar ratio of 6:9:1 was found [119]. The stabilization of $\mathrm{LiNH}_{2}$, the product of $6 \mathrm{Mg}\left(\mathrm{NH}_{2}\right)_{2}+9 \mathrm{LiH}$, by adding $\mathrm{LiBH}_{4}$ (Equation (11)) leads to a theoretical dehydrogenation pressure of 1 bar at ca. $64{ }^{\circ} \mathrm{C}$ in the $6 \mathrm{Mg}\left(\mathrm{NH}_{2}\right)_{2}+9 \mathrm{LiH}+\mathrm{LiBH}_{4}$ system:

$$
6 \mathrm{Mg}\left(\mathrm{NH}_{2}\right)_{2}+9 \mathrm{LiH}+\mathrm{LiBH}_{4} \leftrightarrow 3 \mathrm{Li}_{2} \mathrm{Mg}_{2}(\mathrm{NH})_{3}+\mathrm{Li}_{4}\left(\mathrm{BH}_{4}\right)\left(\mathrm{NH}_{2}\right)_{3}+9 \mathrm{H}_{2}
$$

To understand the reason for the high dehydrogenation plateau (PCI curves) at the starting stage of dehydrogenation of $6 \mathrm{Mg}\left(\mathrm{NH}_{2}\right)_{2}+9 \mathrm{LiH}+\mathrm{LiBH}_{4}$, a systematic investigation of the influence of the reactants ratios was carried out [120-122]. Increasing the ratio of $\mathrm{LiBH}_{4}$ in the system $6 \mathrm{Mg}\left(\mathrm{NH}_{2}\right)_{2}+9 \mathrm{LiH}+\mathrm{xLiBH}_{4}$ to 12 , the dehydrogenation enthalpy decreases to $24 \mathrm{~kJ} / \mathrm{mol} \mathrm{H}_{2}$ (Figure 5a), allowing to achieve the theoretical equilibrium hydrogen pressure of 1 bar below room temperature. The reason behind this interesting property is the role played by the addition of high amount of $\mathrm{LiBH}_{4}$ which strongly influences the dehydrogenation pathway. PCI curves of $6 \mathrm{Mg}\left(\mathrm{NH}_{2}\right)_{2}$ $+9 \mathrm{LiH}+12 \mathrm{LiBH}_{4}$ show the existence of two plateaus, one at high pressure and another having a sloppy appearance (Figure $5 b$ ). The overall dehydrogenation reaction for the PCI process has been proposed to be as follows: firstly, dehydrogenation occurs from the reaction between $\mathrm{Mg}\left(\mathrm{NH}_{2}\right)_{2}$ and $\mathrm{LiH}$, forming $\mathrm{MgNH}, \mathrm{LiNH}_{2}$ and $\mathrm{H}_{2}$; then the as-formed $\mathrm{LiNH}_{2}$ surrounded by $\mathrm{LiBH}_{4}$ produces a mixture of $\mathrm{LiNH}_{2}-2 \mathrm{LiBH}_{4}$ (Equation (12)). This is the reason for the presence of the high-pressure plateau in the PCI curves (Figure 5b). Secondly, $\mathrm{LiNH}_{2}$ reacts with $\mathrm{LiH}$ to form $\mathrm{H}_{2}$ and $\mathrm{Li}_{2} \mathrm{NH}$ with the help of $\mathrm{LiBH}_{4}$, leading to the $\mathrm{H}_{2}$ desorption in the sloppy pressure region (Equation (13)) [122]:

$$
2 \mathrm{Mg}\left(\mathrm{NH}_{2}\right)_{2}(\mathrm{~s})+2 \mathrm{LiH}(\mathrm{s})+4 \mathrm{LiBH}_{4}(\mathrm{~s}) \leftrightarrow 2 \mathrm{MgNH}(\mathrm{s})+2\left[\mathrm{LiNH}_{2}+2 \mathrm{LiBH}_{4}\right](\mathrm{l})+2 \mathrm{H}_{2}(\mathrm{~g})
$$


The volumetric characterization of this system shows a significant release of hydrogen around $98^{\circ} \mathrm{C}$, close to the operating temperature of PEM fuel cell. However, very fast kinetics, suitable for practical applications, are possible only at $143^{\circ} \mathrm{C}$.
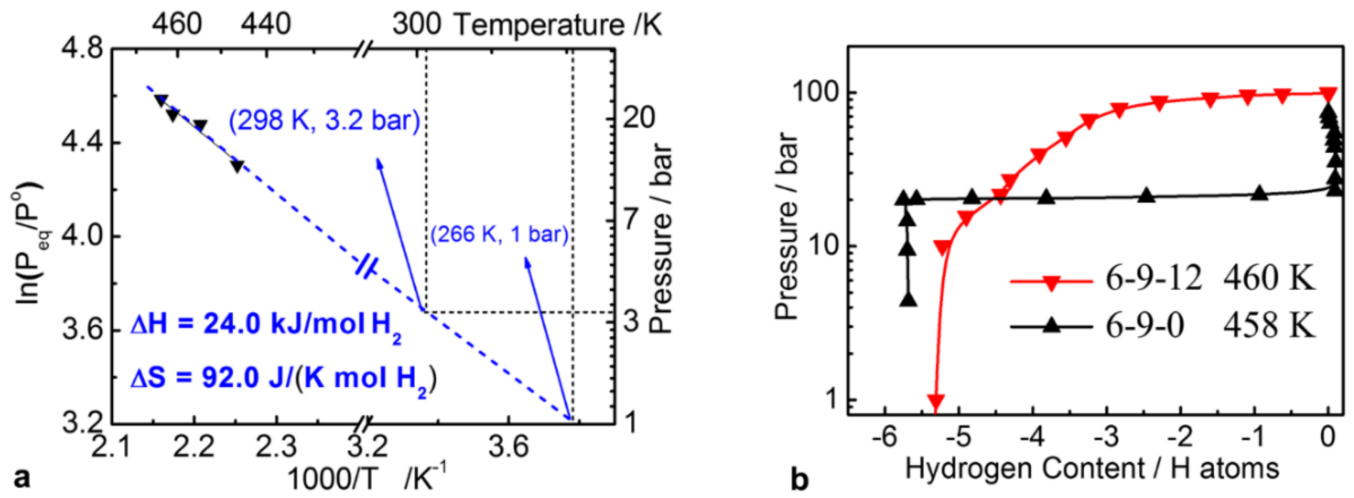

Figure 5. (a) van't Hoff plot of $6 \mathrm{Mg}\left(\mathrm{NH}_{2}\right)_{2}+9 \mathrm{LiH}+12 \mathrm{LiBH}_{4} ;$ (b) PCI curves for $6 \mathrm{Mg}\left(\mathrm{NH}_{2}\right)_{2}+9 \mathrm{LiH}+$ $12 \mathrm{LiBH}_{4}$ and $6 \mathrm{Mg}\left(\mathrm{NH}_{2}\right)_{2}+9 \mathrm{LiH}$ at ca. $460 \mathrm{~K}$ [122].

Similarly to the reaction between $\mathrm{LiNH}_{2}$ and $\mathrm{LiBH}_{4}, \mathrm{Li}_{2} \mathrm{NH}$ can also react with $\mathrm{LiBH}_{4}$ forming several different compounds [123-125]. Interestingly, these compounds have extremely appealing $\mathrm{Li}^{+}$ ion conductivity. The ionic conductivity of such compounds is a key factor in improving the kinetic properties of the $\mathrm{Mg}\left(\mathrm{NH}_{2}\right)_{2}+\mathrm{LiH}$ system [126,127]. Examples of such compounds in the $\mathrm{Mg}\left(\mathrm{NH}_{2}\right)_{2}+$ $\mathrm{LiH}+x \mathrm{LiBH}_{4}$ system are $\mathrm{Li}_{2}\left(\mathrm{BH}_{4}\right)\left(\mathrm{NH}_{2}\right), \mathrm{Li}_{3}\left(\mathrm{BH}_{4}\right)\left(\mathrm{NH}_{2}\right)_{2}$, and $\mathrm{Li}_{4}\left(\mathrm{BH}_{4}\right)\left(\mathrm{NH}_{2}\right)_{3}$. The $\mathrm{Li}^{+}$conductivity of $\mathrm{Li}_{2}\left(\mathrm{BH}_{4}\right)\left(\mathrm{NH}_{2}\right)$ is around $2 \times 10^{-4} \mathrm{~S} \mathrm{~cm}^{-1}$ at room temperature (RT). Upon heating to $105^{\circ} \mathrm{C}$, its conductivity reaches to $6 \times 10^{-2} \mathrm{~S} \mathrm{~cm}^{-1}$. $\mathrm{Li}_{4}\left(\mathrm{BH}_{4}\right)\left(\mathrm{NH}_{2}\right)_{3}$ also possesses a high $\mathrm{Li}^{+}$conductivity of $2 \times 10^{-4} \mathrm{~S} \mathrm{~cm}^{-1}$ and $1 \times 10^{-3} \mathrm{~S} \mathrm{~cm}^{-1}$ at RT and $100{ }^{\circ} \mathrm{C}$, respectively [128].

Recently, various transition metal salts [129-135] were tested as additives to further improve the hydrogen properties of the $\mathrm{LiBH}_{4}$-doped Li-Mg-N-H system. For example, $\mathrm{Li}_{3} \mathrm{~N}$ and $\mathrm{YCl}_{3}$ have been used as co-additives for $6 \mathrm{Mg}\left(\mathrm{NH}_{2}\right)_{2}+9 \mathrm{LiH}+\mathrm{xLiBH}_{4}$. The co-additives improve the hydrogen storage capacity and the de/absorption kinetics. $4.2 \mathrm{wt}$. \% of hydrogen was charged in only $8 \mathrm{~min}$ under isothermal conditions at $180{ }^{\circ} \mathrm{C}$ and 85 bar of hydrogen pressure. Furthermore, by increasing the $\mathrm{H}_{2}$ pressure above 185 bars, the absorption process can be performed under milder temperature conditions below $90{ }^{\circ} \mathrm{C}$. These hydrogenation capacity and absorption kinetics can be maintained constant for more than 10 cycles [135]. The reaction mechanism depicted in Figure 6, proposed for the hydrogenation step, reveals that hydrogen is firstly dissociated by the action of the additive and then interacts with the ternary imide $\mathrm{Li}_{2} \mathrm{Mg}(\mathrm{NH})_{2}$ forming the binary system $\mathrm{Mg}\left(\mathrm{NH}_{2}\right)_{2}-\mathrm{LiH}$. The diffusion of hydrogen and the mass transfer is ruled by the liquid matrix $\mathrm{Li}_{4}\left(\mathrm{BH}_{4}\right)\left(\mathrm{NH}_{2}\right)_{3}$. 


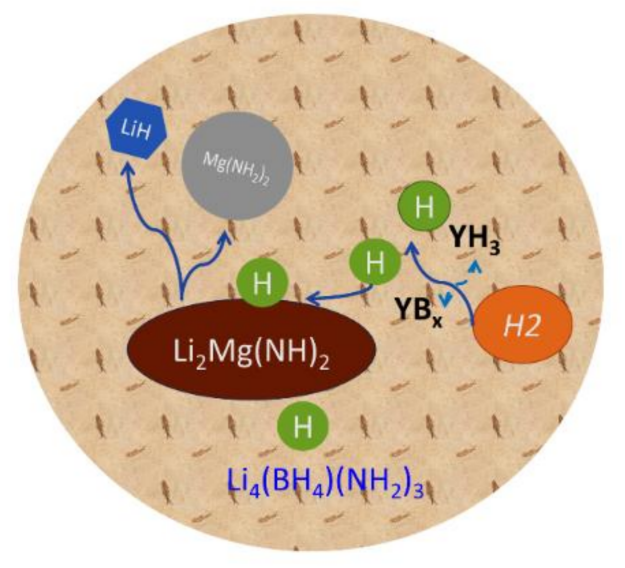

Figure 6. Scheme of the reaction mechanism proposed for the re-hydrogenation step in the co-additive $6 \mathrm{Mg}\left(\mathrm{NH}_{2}\right)_{2}+9 \mathrm{LiH}+\mathrm{xLiBH}_{4}$ systems [128].

The effect of some nanoadditives such as $\mathrm{Ni}, \mathrm{Co}, \mathrm{Fe}, \mathrm{Cu}$, and $\mathrm{Mn}$ have been investigated by Srinivasan et al. [129] for the $2 \mathrm{LiNH}_{2}+1.1 \mathrm{MgH}_{2}+0.1 \mathrm{LiBH}_{4}$ system, previously introduced in the Section 3. As the result of this investigation, it was found that some of these additives (Co, Ni) reduce the de-hydrogenation temperature of more than $75^{\circ} \mathrm{C}$; some others $(\mathrm{Cu}, \mathrm{Fe})$ increase significantly the de-hydrogenation rate.

However, one of the most efficient additives for the $2 \mathrm{LiNH}_{2}+1.1 \mathrm{MgH}_{2}+0.1 \mathrm{LiBH}_{4}$ system still remains $\mathrm{ZrCoH}_{3}$ [130]. The addition of $3 \mathrm{wt}$. \% of $\mathrm{ZrCoH}_{3}$ to this system leads to absorb $5.3 \mathrm{wt}$. \% of $\mathrm{H}_{2}$ under 70 bar of $\mathrm{H}_{2}$ pressure in $10 \mathrm{~min}$ and desorb 3.8 wt. \% of $\mathrm{H}_{2}$ under 1 bar $\mathrm{H}_{2}$ pressure in $60 \mathrm{~min}$ at $150^{\circ} \mathrm{C}$. X-ray absorption fine structure (XAFS) study suggests that the chemical environment of both $\mathrm{Zr}$ and $\mathrm{Co}$ atoms and the crystal parameters of $\mathrm{ZrCoH}_{3}$ remain unchanged during de/re-hydrogenation processes. These results point out to the fact that $\mathrm{ZrCoH}_{3}$ works as a catalyst in this ternary composition [131]. $2 \mathrm{LiNH}_{2}+1.1 \mathrm{MgH}_{2}+0.1 \mathrm{LiBH}_{4}-3$ wt. $\% \mathrm{ZrCoH}_{3}$ has been considered as one of the most promising materials for possible real scale applications owing to its excellent hydrogen storage properties [136-138]. A prototype tank to feed a $1 \mathrm{~kW}$ HT-PEM stack for an Auxiliary Power Unit (APU), was built using this ternary system as storage material. The gravimetric capacity of this tank was roughly $2.1 \mathrm{wt}$. $\%$, fully reversible at the temperature range of $160-180{ }^{\circ} \mathrm{C}$ [138].

Other borohydrides such as $\mathrm{Mg}\left(\mathrm{BH}_{4}\right)_{2}$ [139-141] and $\mathrm{Ca}\left(\mathrm{BH}_{4}\right)_{2}$ [142] were also added to the system, and similar effects to that of $\mathrm{LiBH}_{4}$ were observed. For example, the $\mathrm{Mg}\left(\mathrm{NH}_{2}\right)_{2}+2 \mathrm{LiH}+$ $0.1 \mathrm{Mg}\left(\mathrm{BH}_{4}\right)_{2}$ sample can reversibly de/re-hydrogenate $\sim 4.5 \mathrm{wt}$. \% of $\mathrm{H}_{2}$ at 140 and $120{ }^{\circ} \mathrm{C} . \mathrm{Mg}\left(\mathrm{BH}_{4}\right)_{2}$ and $\mathrm{LiH}$ convert to $\mathrm{LiBH}_{4}$ and $\mathrm{MgH}_{2}$ during ball milling, subsequently, the as formed $\mathrm{MgH}_{2}$ reacts with $\mathrm{Mg}\left(\mathrm{NH}_{2}\right)_{2}$ to form $\mathrm{MgNH}$. Upon heating, $\mathrm{LiBH}_{4}$ support the recrystallization of $\mathrm{Mg}\left(\mathrm{NH}_{2}\right)_{2}$ and reacts with $\mathrm{LiNH}_{2}$ to form $\mathrm{Li}_{4}\left(\mathrm{BH}_{4}\right)\left(\mathrm{NH}_{2}\right)_{3}$. Meanwhile, MgNH may act as a seeding agent for $\mathrm{Li}_{2} \mathrm{Mg}(\mathrm{NH})_{2}$ leading to a fast dehydrogenation of $\mathrm{Mg}\left(\mathrm{NH}_{2}\right)_{2}$ and $\mathrm{LiH}$ as the consequence of the structural similarity. Thus, the as formed $\mathrm{LiBH}_{4}$ and $\mathrm{MgNH}$ synergistically influence the hydrogen storage performances of the $\mathrm{Mg}\left(\mathrm{NH}_{2}\right)_{2}+2 \mathrm{LiH}$ system [140]. Recently, $\mathrm{Li}_{4}\left(\mathrm{BH}_{4}\right)\left(\mathrm{NH}_{2}\right)_{3}$ has also been tested as an additive to alter the hydrogen storage properties of the $\mathrm{Li}-\mathrm{Mg}-\mathrm{N}-\mathrm{H}$ system due to its low melting point and fast $\mathrm{Li}^{+}$ion conductivity [143-146].

\section{Ternary Transition Metal Amide-Hydride System}

Various amide-hydride systems with different kinetics and thermodynamics have been developed by the combination and/or replacement of several amides and/or hydrides. Meanwhile, doping with transition metal/salt such as $\mathrm{Sc}, \mathrm{Ti}, \mathrm{V}, \mathrm{Ta}, \mathrm{Ni}$ et al. has demonstrated to be an effective way to improve the hydrogen storage properties of amide-hydride system. The hydrogen sorption properties of $\mathrm{LiNH}_{2}$ 
$+\mathrm{LiH}$ can be significantly improved by doping it with nanosized Ti-based additives. In fact, this system can desorb roughly $5.5 \mathrm{wt}$. $\% \mathrm{H}_{2}$ within a temperature range of 150 to $250^{\circ} \mathrm{C}$.

Considering the advantages achievable by following both ways of improving the hydrogen storage performance, recently we introduced several ternary alkali metal transition metal amides as hydrogen storage materials after mixing them with $\mathrm{LiH}$. For some of the investigated systems, outstanding absorption kinetics have been observed. As an example, the product of the decomposition of $\mathrm{K}_{2}\left[\mathrm{Zn}\left(\mathrm{NH}_{2}\right)_{4}\right]+8 \mathrm{LiH}$ can be fully hydrogenated within $30 \mathrm{~s}$, as reported in Figure 7, at $230^{\circ} \mathrm{C}$ and 50 bar of $\mathrm{H}_{2}$ [147]. Similar phenomenon was also observed in $\mathrm{K}_{2}\left[\mathrm{Mn}\left(\mathrm{NH}_{2}\right)_{4}\right]+8 \mathrm{LiH}$ under the same temperature and hydrogen pressure conditions [148].
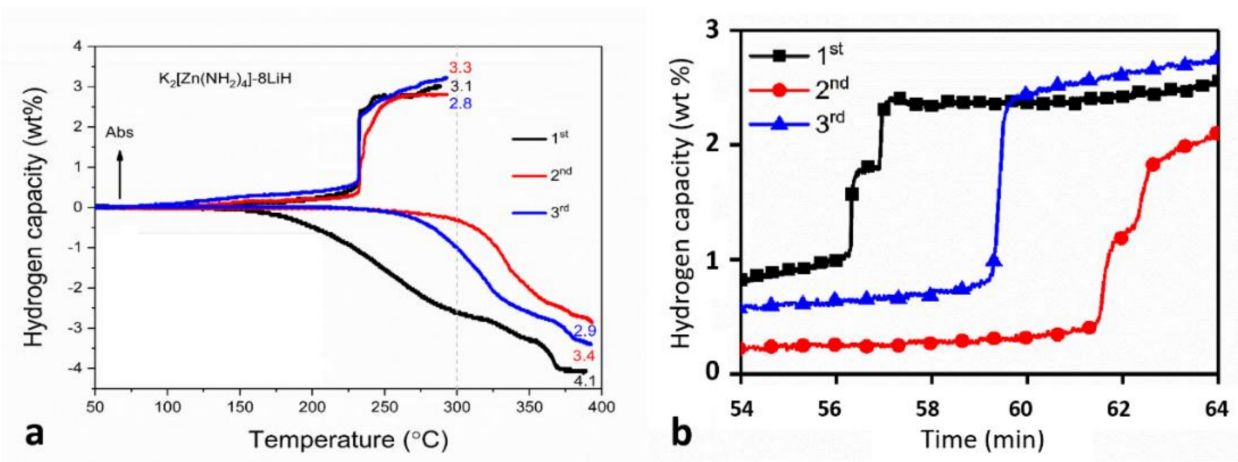

Figure 7. Volumetric desorption and absorption cycles of the $\mathrm{K}_{2}\left[\mathrm{Zn}\left(\mathrm{NH}_{2}\right)_{4}\right]+8 \mathrm{LiH}$ system vs. temperature (a) and time (b). The desorption step has been performed from room temperature to $400{ }^{\circ} \mathrm{C}\left(3{ }^{\circ} \mathrm{C} / \mathrm{min}\right)$ under static vacuum while the absorption from room temperature to $300{ }^{\circ} \mathrm{C}$ $\left(3^{\circ} \mathrm{C} / \mathrm{min}\right)$ under 50 bar $_{2}$. [147].

The details of the reaction pathway of $\mathrm{K}_{2}\left[\mathrm{Zn}\left(\mathrm{NH}_{2}\right)_{4}\right]+8 \mathrm{LiH}$ system were investigated by means of in situ X-ray diffraction studies (Figure 8) [149]. This study showed that $\mathrm{K}_{2}\left[\mathrm{Zn}\left(\mathrm{NH}_{2}\right)_{4}\right]+8 \mathrm{LiH}$ converts to $4 \mathrm{LiNH}_{2}+4 \mathrm{LiH}+\mathrm{K}_{2} \mathrm{ZnH}_{4}$ during milling; upon heating, $4 \mathrm{LiNH}_{2}+4 \mathrm{LiH}+\mathrm{K}_{2} \mathrm{ZnH}_{4}$ releases $\mathrm{H}_{2}$ in multiple steps. The final dehydrogenation products are $\mathrm{KH}, \mathrm{LiZn}_{13}$, and $\mathrm{Li}_{2} \mathrm{NH}$. During absorption, $\mathrm{KH}$ reacts with $\mathrm{LiZn}_{13}$ under 50 bar of $\mathrm{H}_{2}$ to form $\mathrm{K}_{3} \mathrm{ZnH}_{5}$. This phase most likely is the key to enhance the re-hydrogenation process; thanks to the existence of $\mathrm{K}_{3} \mathrm{ZnH}_{5}$, the absorption reaction takes place in only $30 \mathrm{~s}$ at ca. $220^{\circ} \mathrm{C}$ [149]. Inspired by these works, a large variety of ternary metal transition amides can be produced opening new perspectives for the development of systems which can ab/desorbs hydrogen at lower temperatures more suitable for practical applications.

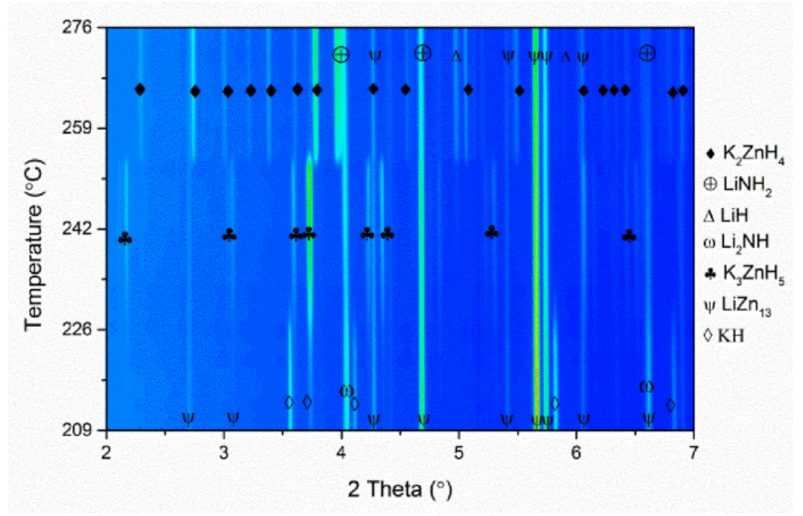

Figure 8. Re-hydrogenation contour plot of the $\mathrm{K}_{2}\left[\mathrm{Zn}\left(\mathrm{NH}_{2}\right)_{4}\right]+8 \mathrm{LiH}$ composite at the temperature range between 209 and $276{ }^{\circ} \mathrm{C}$ (heating rate of $2{ }^{\circ} \mathrm{C} / \mathrm{min}, \lambda=0.20775 \AA$ ) [149]. 


\section{Sodium-Based Composites}

In the last 10 years, the ever-increasing cost of lithium on a worldwide scale has encouraged the search for lithium-free metal amides systems with high-performing properties for on-board applications, which can replace the most expensive Li-based amides. $\mathrm{NaNH}_{2}$ and its composites, in particular, have attracted a lot of attentions because its considerable high amount of hydrogen, low cost and interesting thermodynamic properties [150-154].

Due to its high catalytic activity in the decomposition of $\mathrm{NH}_{3}$, pure sodium amide, has been considered as potential material also for other applications different from solid-state hydrogen storage. In this context, its decomposition path has been topic of debate. Recently, two different decomposition paths have been presented. Jain et al. [151], proposed that $\mathrm{NaNH}_{2}$, after melting at $200{ }^{\circ} \mathrm{C}$, decomposes to sodium, ammonia and nitrogen $\left(>400^{\circ} \mathrm{C}\right)$, without passing for its corresponding nitride and / or imide phase as, on the other hand, shown by $\mathrm{LiNH}_{2}$ and $\mathrm{Mg}\left(\mathrm{NH}_{2}\right)_{2}$. Recently, different results have been obtained by Miyaoka and coauthors, where the thermal decomposition of sodium amide was studied under different experimental conditions [154]. From this specific study emerged that the decomposition reaction products depend on the pressure conditions. The authors discovered a new intermediate, an imide-like phase with a cubic structure, which decomposes to sodium, at $400{ }^{\circ} \mathrm{C}$, under vacuum, while, for the closed system, the partial pressure of hydrogen promotes the formation of sodium hydride [154].

A significant reduction of the hydrogen desorption temperatures, has been successfully obtained for composite systems. For example, Pecharsky et al. [153] reported that the $2 \mathrm{NaNH}_{2}+3 \mathrm{MgH}_{2}$ system released hydrogen in the temperature range of $130-400{ }^{\circ} \mathrm{C}$ (vs. $186{ }^{\circ} \mathrm{C}-400{ }^{\circ} \mathrm{C}$ for $2 \mathrm{LiNH}_{2}+3 \mathrm{MgH}_{2}$ ) following the Equation (14):

$$
2 \mathrm{NaNH}_{2}+3 \mathrm{MgH}_{2} \rightarrow \mathrm{Mg}_{3} \mathrm{~N}_{2}+2 \mathrm{NaH}+\mathrm{H}_{2}
$$

A total release of $5.1 \mathrm{H}_{2}$ wt. $\%$ was finally achieved at $400{ }^{\circ} \mathrm{C}$. The decomposition path summarized in Equation (14) proceeds with a series of competitive solid-state process including the formation of $\mathrm{Mg}\left(\mathrm{NH}_{2}\right)_{2}$ at low temperature $\left(>140^{\circ} \mathrm{C}\right)$, which suggests that a metathesis reaction occurred. Only $2.1 \mathrm{wt}$. \% of hydrogen could be re-absorbed at $395^{\circ} \mathrm{C}$ under 190 bars of hydrogen, probably because, at this high temperature, $\mathrm{NaH}$ is liquid and/or decomposes to $\mathrm{Na}$. However, any absorption was achieved at lower temperatures. New insights on the desorption pathway of $\mathrm{NaNH}_{2} / \mathrm{MgH}_{2}$ were obtained by Sheppard and collaborators [152]. $3.3 \mathrm{wt}$. \% of hydrogen was in fact desorbed between 70 and $335^{\circ} \mathrm{C}$ in the equimolar milled system with the formation of two new magnesium-containing imide and nitride phases during the dehydrogenation. Despite the lower desorption temperature with respect the 3:2 system, the kinetic desorption remains a not yet solved limitation for this mixture even after the addition of catalysts such as $\mathrm{TiCl}_{3}$.

Effect of high-energy ball milling on the $\mathrm{NaNH}_{2} / \mathrm{MgH}_{2}$ systems with different stoichiometry, 2:1 and 2:3, have also been evaluated [155-157]. The mechanically activated metathesis reaction occurred for the 2:1 system, ball milled for a prolonged milling time. Without releasing of hydrogen gas. Conversely to the thermally activated process, which exhibits solid intermediates, only the formation of $\mathrm{Mg}\left(\mathrm{NH}_{2}\right)_{2}$ and $\mathrm{NaH}$ phases were observed upon the extended mechanical treatment $(50 \mathrm{~h})$. This represented a valid strategy to prepare the $\mathrm{Mg}\left(\mathrm{NH}_{2}\right)_{2}-\mathrm{NaH}$ system in nanostructured conditions. However, in the same work, it emerged that the desorption properties cannot be interesting for practical applications [156]. This evidence was also confirmed by a previous work, published by Chen et al. devoted to the study of the Mg-Na-N-H system [158]. $\mathrm{Mg}\left(\mathrm{NH}_{2}\right)_{2}$ was mixed with different amounts of $\mathrm{NaH}$ and the hydrogen storage properties tested. Working temperatures lower than $200^{\circ} \mathrm{C}$ were observed but only $2.17 \mathrm{wt}$. \% of hydrogen could be reversibly desorbed, which implies a scarce interest from a practical applications point of view.

One of the most important benefit recognized to the addition of metal hydrides to sodium amide, is represented by the ammonia suppression during the thermal decomposition step, as reported by 
Jain et al. [159] In this work, NaH has been shown to efficiently suppress the emission of ammonia gas when added to $\mathrm{NaNH}_{2}$. Furthermore, a clear picture of the mechanism involved in this process has been reported for an extended number of amide hydride systems: the dehydrogenation process occurred with the formation of double-cation amides, which decrease the hydrogen desorption temperatures (except for the $\mathrm{CaH}_{2}$-containing system) [159].

A further way to destabilize $\mathrm{NaNH}_{2}$ is represented by the addition of complex hydrides, such as $\mathrm{NaBH}_{4}, \mathrm{Ca}\left(\mathrm{BH}_{4}\right)_{2}$ and $\mathrm{Mg}\left(\mathrm{BH}_{4}\right)_{2}$ in stochiometric amount [150,158,160-163]. For example, the starting reagents $\mathrm{NaNH}_{2}-\mathrm{NaBH}_{4}$ (2:1) when subjected to intensive ball milling, react producing $\mathrm{Na}_{3}\left(\mathrm{NH}_{2}\right)_{2} \mathrm{BH}_{4}$. This new phase desorbed hydrogen ( $6.85 \mathrm{wt}$. \%) gas forming $\mathrm{Na}_{3} \mathrm{BN}_{2}$ [162]. The desorption path is characterized by two main steps: the first in the temperature range $70-170{ }^{\circ} \mathrm{C}$, while the second one between $190-420^{\circ} \mathrm{C}$. At higher temperatures, $\mathrm{Na}_{3} \mathrm{BN}_{2}$ decomposes to $\mathrm{Na}$. The activation energy of this system was estimated to be $159.6 \mathrm{~kJ} / \mathrm{mol}$, and it can be significantly reduced to $70 \mathrm{~kJ} / \mathrm{mol}$ by the addition of Co-B catalyst [163]. A comparable kinetic enhancement was also reached for the un-doped 2:1 system prepared by liquid phase ball milling $\left(E_{a}=76.4 \mathrm{~kJ} / \mathrm{mol}\right)$ instead of the classical dry milling, paving the way for the exploration of a new efficient synthetic route for this kind of composites [161]. Synergetic effect of the liquid phase ball milling preparation and the addition of Co-Ni-B dopant, contributed to significantly improve the kinetic performance of the dehydrogenation step further lowering the activation energy to $68.2 \mathrm{~kJ} / \mathrm{mol}$ and the thermodynamic property of the system. In fact, $5.05 \mathrm{wt}$. \% of hydrogen was successfully desorbed at temperature below $200{ }^{\circ} \mathrm{C}$ [163].

Concerning the addition of $\mathrm{Mg}\left(\mathrm{BH}_{4}\right)_{2}$ and $\mathrm{Ca}\left(\mathrm{BH}_{4}\right)_{2}$, a very recent and detailed structural investigation was performed for different compositions [160]. Both the systems desorbed by the emission of undesired ammonia gas at low temperature while the formation of $\mathrm{NaBH}_{4}$ occurred through a metathesis reaction between $\mathrm{NaNH}_{2}$ and $\mathrm{M}\left(\mathrm{BH}_{4}\right)_{2}(\mathrm{M}=\mathrm{Mg}, \mathrm{Ca})$. Hydrogen gas evolution started only at temperature higher than $350^{\circ} \mathrm{C}$ for the $1: 2$ system and above $450{ }^{\circ} \mathrm{C}$ for the equimolar 1:1 composites, making these systems not properly suitable for on-board applications.

Finally, different studies have also been focused on the opportunity to improve the hydrogen storage properties of $\mathrm{NaNH}_{2}$ by combining it with $\mathrm{LiAlH}_{4}$ as effectively occurred for $\mathrm{LiNH}_{2}$ [164-167]. In this context, Xiong et al. proved that during ball milling a solid-state interaction between $\mathrm{NaNH}_{2}$ and $\mathrm{LiAlH}_{4}$ took place, leading to the formation of the tetramide $\mathrm{Li}_{3} \mathrm{Na}\left(\mathrm{NH}_{2}\right)_{4}$ which seems to favor the desorption at lower temperatures [166]. Recently, Jensen and coauthors synthesized, by high-energy ball milling the lithium sodium tetramide and corroborated its key role together with $\operatorname{LiNa}_{2}\left(\mathrm{NH}_{2}\right)_{3}$, in the destabilization of different sodium-based systems [165]. For example, $\mathrm{LiNH}_{2}-\mathrm{NaH}$ and $\mathrm{NaNH}_{2}-\mathrm{LiH}$ desorbed 0.9 wt. \% of hydrogen from 180 to $340{ }^{\circ} \mathrm{C}$ with a faster kinetic if compared with the most explored $\mathrm{LiNH}_{2}+\mathrm{LiH}$ system. Unfortunately, as emerged from in situ synchrotron X-ray powder diffraction (XRPD) studies, imides and nitrides cannot be formed under moderate temperatures, which implies the irreversibility of these systems.

\section{Concluding Remarks}

The technological challenges connected with the exploitation of solid materials for storing efficiently hydrogen are primary sources of interest, and the opportunity to use metal amides-based composites in this specific area captures the attention of an increasing number of scientists. From the overview offered in Section 2, it is clear that the Li-N-H system, despite of the encouraging results recently obtained, possess several limitations, in particular from the thermodynamic point of view, which are in part mitigated when $\mathrm{Li}$ is partially replaced by $\mathrm{Mg}$, forming the $\mathrm{Li}-\mathrm{Mg}-\mathrm{N}-\mathrm{H}$ system. The latter, in fact, shows more suitable thermodynamic properties and superior kinetics when compared with the first one. To get light on the promising properties of these systems, the thermodynamic and kinetics features of the most appealing mixtures, experimentally achieved, have been summarized in Table 1. 
Table 1. Thermodynamic and kinetic data of some Li-Mg-N-H systems.

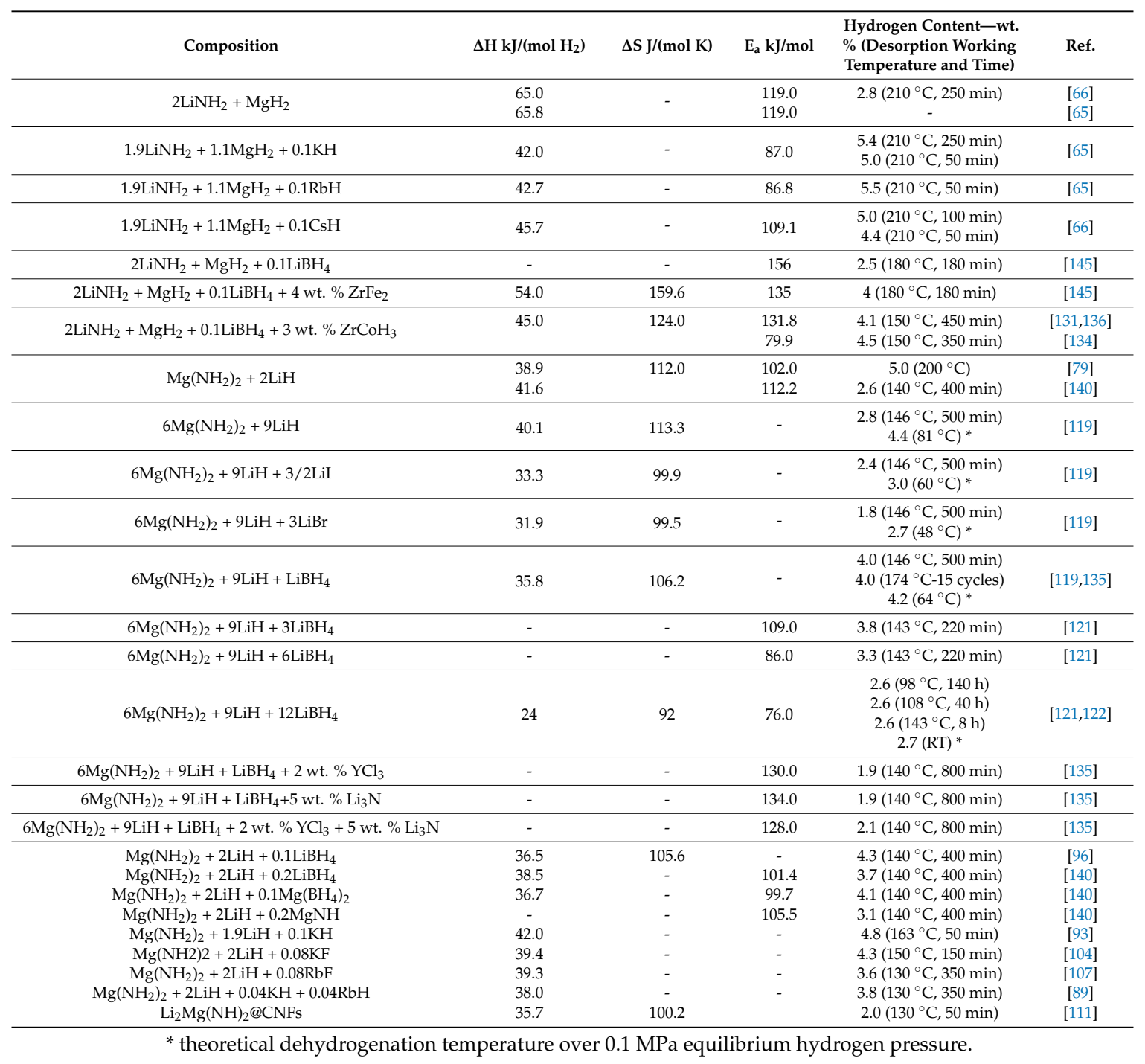

Depending on the dopant, the $2 \mathrm{LiNH}_{2}+\mathrm{MgH}_{2}$ system shows different behaviors. In comparison to the un-doped material, the addition of additives based on $\mathrm{KH} ; \mathrm{RbH}$ and $\mathrm{CsH}$, (Figure 9), lead to significant thermodynamic and kinetic improvements. The introduction of $\mathrm{LiBH}_{4}$ contributes to decrease the temperature of hydrogen release from $210^{\circ} \mathrm{C}$ to $180^{\circ} \mathrm{C}$, however, the gravimetric capacity of the system is affected. An important enhancement is produced when this composite is doped with $\mathrm{ZrFe}_{2}$ and $\mathrm{ZrCoH}_{3}$, as clearly emerged by the bars in Figure 10. The system containing $\mathrm{ZrCoH}_{3}$ has been extensively investigated and, up to day, among the metal amide-based family, it is probably the only system tested under near practical conditions [137].

Interestingly, the working temperature can be further decreased inverting the system cations, i.e., $\mathrm{Mg}\left(\mathrm{NH}_{2}\right)_{2}-\mathrm{LiH}$. This composite presents several advantages such as reduced or almost suppressed ammonia emissions, working temperatures of about $150^{\circ} \mathrm{C}$ and good gravimetric capacity if compared with the previous composites (Figure 10). For this system, the enthalpy is reduced from $\sim 50 \mathrm{~kJ} / \mathrm{mol}$ $\mathrm{H}_{2}$ of the $\mathrm{LiNH}_{2} / \mathrm{MgH}_{2}$-based mixtures to $\sim 40 \mathrm{~kJ} / \mathrm{mol} \mathrm{H}_{2}$. However, as also evidenced in Table 1 , the data concerning the activation energy of the dehydrogenation process are quite scarce and more efforts have to be made to obtain a more detailed picture of this system. 


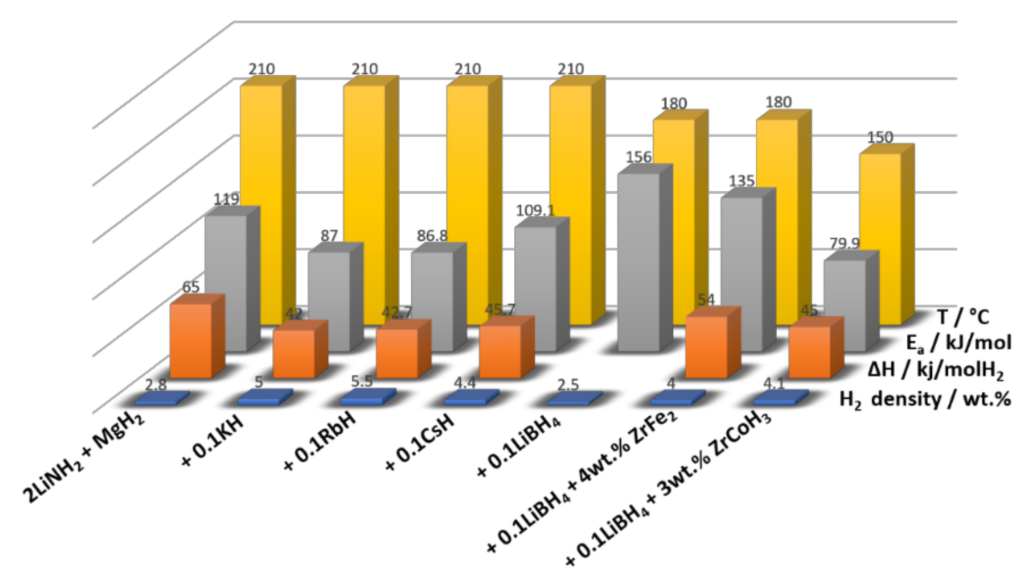

Figure 9. Experimental thermodynamic and kinetic data for the un-doped and doped $2 \mathrm{LiNH}_{2}+$ $\mathrm{MgH}_{2}$ systems.

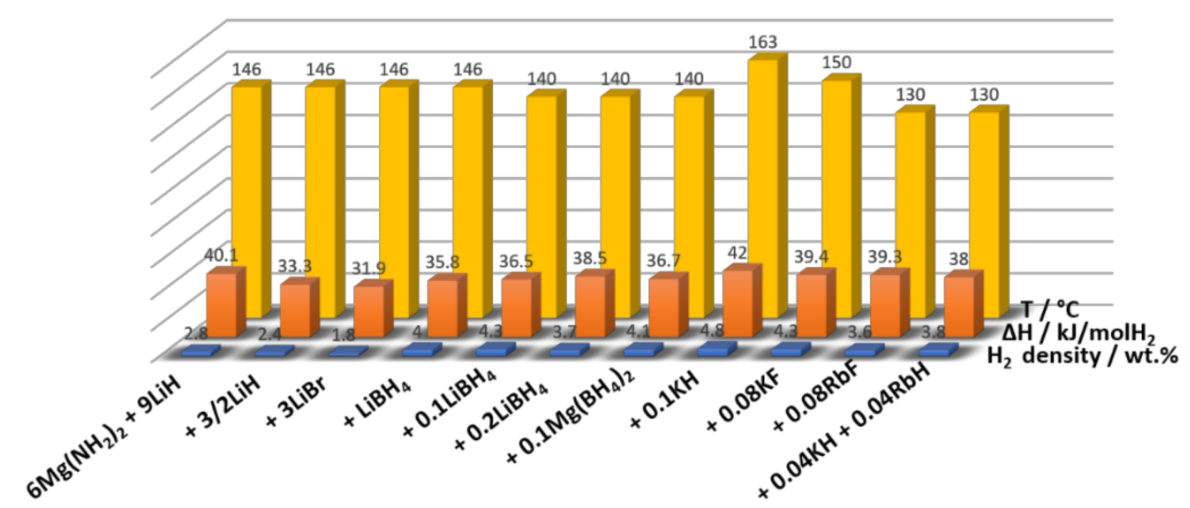

Figure 10. Experimental thermodynamic and kinetic data for the un-doped and doped $\mathrm{Mg}\left(\mathrm{NH}_{2}\right)_{2}+$ 2LiH systems.

In order to better discriminate among the most appealing systems which approach to the targets fixed by DoE, two main parameters, gravimetric density and working temperature properties have been selected and depicted in Figure 11 for several materials. Other systems not discussed in this review, such as $\mathrm{NH}_{2} \mathrm{NH}_{2}, \mathrm{LiBH}_{4} * \mathrm{~N}_{2} \mathrm{H}_{4}$, metal borohydrides, etc., have been also included in the graph, for comparison purpose. Form these data it is possible to evince that, by now, there is no amides-based system which can completely fits the specific targets fixed by DoE for 2020 (olivine panel in Figure 11). However, it is important to highlight the important progresses made in the last years in term of effective working temperature. In particular, the ternary system $\mathrm{Mg}\left(\mathrm{NH}_{2}\right)_{2}+\mathrm{LiH}+$ $\mathrm{LiBH}_{4}$ shows a working temperature close to the desired room temperature. $\mathrm{LiBH}_{4}$ is proved to have an extraordinary effect in tuning the thermodynamic properties of the Li-Mg-N-H system. Likewise, nanoparticles of $\mathrm{Li}_{2} \mathrm{Mg}(\mathrm{NH})_{2}$ encapsulated into carbon nanofiber matrix possess suitable temperature to be candidate as promising material for practical application. However, the hydrogen release under these operative conditions is not enough to satisfy the expected requirement. 


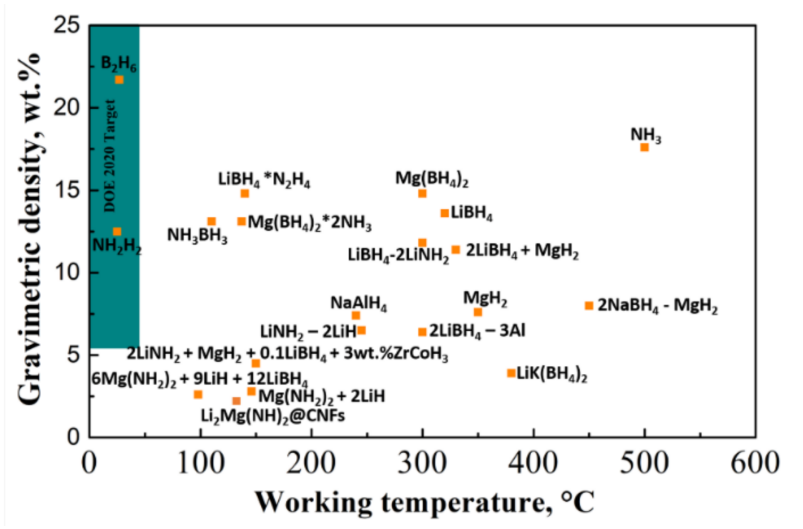

Figure 11. Working gravimetric density and temperatures of some representative materials for hydrogen storage applications.

Furthermore, despite the reaction enthalpy of 24 and $35.7 \mathrm{~kJ} / \mathrm{mol} \mathrm{H}_{2}$, results quite satisfactory, both systems are kinetically hindered. In fact, in the ternary composites desorbs reversibly $2.8 \mathrm{wt}$. \% of hydrogen below $100{ }^{\circ} \mathrm{C}$ only after $140 \mathrm{~h}$. The encapsulated system can reversibly release similar amount of hydrogen with faster kinetic $(50 \mathrm{~min})$ but under higher temperature $\left(130^{\circ} \mathrm{C}\right)$. For this reason, at the moment, kinetic improvement represents the first objective to be accomplished for these systems and many efforts have to be addressed in this direction as future perspective. In this context, solid-state catalysts, using $\mathrm{K}$-and $\mathrm{Rb}$-based additives, or $\mathrm{ZrCoH}_{3}$, can represent a valid strategy, together with a suitable preparation technique, for reaching the expected results for both these systems.

Another challenge is represented by scaling-up the production of the specific systems. This implies to approach two main important aspects: (i) the preparation techniques and (ii) cost of materials. If $\mathrm{Li}_{2} \mathrm{Mg}(\mathrm{NH})_{2} @ \mathrm{CNFs}$ presents a restricted number of solid reagents involved in its preparation, which reduces the whole cost of production, the soft chemistry approach used in this synthesis is, of course, less practicable for producing large amounts of product with respect to the traditional ball milling. Likewise, the cost issue of the starting materials has to be taken in consideration. The commercial prices of the involved materials are reported in Table 2. The actual costs of reagents represent a further barrier for a rapid commercialization of these systems. However, a valid chance, in prospective, can be represented by using cheap raw materials obtained from $\mathrm{Mg}$ and $\mathrm{Li}$ industrial wastes, which can allow to halve the production cost of several amides.

Table 2. Commercial prices of materials involved in the preparation of the metal amides-based composites.

\begin{tabular}{ccccc}
\hline Materials & LiNH $_{\mathbf{2}}$ & $\mathbf{L i H}$ & MgH $_{\mathbf{2}}$ & $\mathbf{L i B H}_{\mathbf{4}}$ \\
\hline Purity $(\%)$ & 95 (Alfa Aesar) 95 & 97 (Alfa Aesar) & $95 \%$ (Albemarle) & 95 (Acros Organics) \\
Price $(€ / \mathrm{kg})$ & 348 & 483 & 600 & 7980 \\
\hline
\end{tabular}

Author Contributions: Antonio Santoru, Hujun Cao, Sebastiano Garroni and Claudio Pistidda realized the structure design of the manuscript and the recovering of the data. Chiara Milanese, Fabiana Gennari, Thomas Klassen and Martin Dornheim contributed to the writing and revision of the review.

Acknowledgments: The authors acknowledge the funding from European Marie Curie Actions under ECOSTORE grant agreement No. 607040.

Conflicts of Interest: The authors declare no conflict of interest.

\section{References}

1. Chen, P.; Xiong, Z.; Luo, J.; Lin, J.; Tan, K.L. Interaction of hydrogen with metal nitrides and imides. Nature 2002, 420, 302-304. [CrossRef] [PubMed] 
2. Chen, P.; Zhu, M. Recent progress in hydrogen storage. Mater. Today 2008, 11, 36-43. [CrossRef]

3. Pinkerton, F. Decomposition kinetics of lithium amide for hydrogen storage materials. J. Alloys Compd. 2005, 400, 76-82. [CrossRef]

4. Chen, P.; Xiong, Z.; Luo, J.; Lin, J.; Tan, K.L. Interaction between lithium amide and lithium hydride. J. Phys. Chem. B 2003, 107, 10967-10970. [CrossRef]

5. Ichikawa, T.; Hanada, N.; Isobe, S.; Leng, H.; Fujii, H. Mechanism of novel reaction from $\mathrm{LiNH}_{2}$ and $\mathrm{LiH}_{\text {to }}$ $\mathrm{Li}_{2} \mathrm{NH}$ and $\mathrm{H}_{2}$ as a promising hydrogen storage system. J. Phys. Chem. B 2004, 108, 7887-7892. [CrossRef]

6. Hino, S.; Ichikawa, T.; Ogita, N.; Udagawa, M.; Fujii, H. Quantitative estimation of $\mathrm{NH}_{3}$ partial pressure in $\mathrm{H}_{2}$ desorbed from the Li-N-H system by Raman spectroscopy. Chem. Commun. 2005, 3038-3040. [CrossRef] [PubMed]

7. Ichikawa, T.; Isobe, S.; Hanada, N.; Fujii, H. Lithium nitride for reversible hydrogen storage. J. Alloys Compd. 2004, 365, 271-276. [CrossRef]

8. Meisner, G.P.; Pinkerton, F.E.; Meyer, M.S.; Balogh, M.P.; Kundrat, M.D. Study of the lithium-nitrogen-hydrogen system. J. Alloys Compd. 2005, 404-406, 24-26. [CrossRef]

9. Ikeda, S.; Kuriyama, N.; Kiyobayashi, T. Simultaneous determination of ammonia emission and hydrogen capacity variation during the cyclic testing for $\mathrm{LiNH}_{2}-\mathrm{LiH}$ hydrogen storage system. Int. J. Hydrogen Energy 2008, 33, 6201-6204. [CrossRef]

10. Matsumoto, M.; Haga, T.; Kawai, Y.; Kojima, Y. Hydrogen desorption reactions of Li-N-H hydrogen storage system: Estimation of activation free energy. J. Alloys Compd. 2007, 439, 358-362. [CrossRef]

11. Ichikawa, T.; Hanada, N.; Isobe, S.; Leng, H.; Fujii, H. Hydrogen storage properties in Ti catalyzed Li-N-H system. J. Alloys Compd. 2005, 404, 435-438. [CrossRef]

12. Lu, C.; Hu, J.; Kwak, J.H.; Yang, Z.; Ren, R.; Markmaitree, T.; Shaw, L.L. Study the effects of mechanical activation on Li-N-H systems with $1 \mathrm{H}$ and 6Li solid-state NMR. J. Power Sources 2007, 170, 419-424. [CrossRef]

13. Shaw, L.L.; Ren, R.; Markmaitree, T.; Osborn, W. Effects of mechanical activation on dehydrogenation of the lithium amide and lithium hydride system. J. Alloys Compd. 2008, 448, 263-271. [CrossRef]

14. Osborn, W.; Markmaitree, T.; Shaw, L.L.; Hu, J.-Z.; Kwak, J.; Yang, Z. Low temperature milling of the $\mathrm{LiNH}_{2}$ + LiH hydrogen storage system. Int. J. Hydrogen Energy 2009, 34, 4331-4339. [CrossRef]

15. Varin, R.; Jang, M.; Polanski, M. The effects of ball milling and molar ratio of LiH on the hydrogen storage properties of nanocrystalline lithium amide and lithium hydride $\left(\mathrm{LiNH}_{2}+\mathrm{LiH}\right)$ system. J. Alloys Compd. 2010, 491, 658-667. [CrossRef]

16. Varin, R.; Jang, M. The effects of graphite on the reversible hydrogen storage of nanostructured lithium amide and lithium hydride $\left(\mathrm{LiNH}_{2}+1.2 \mathrm{LiH}\right)$ system. J. Alloys Compd. 2011, 509, 7143-7151. [CrossRef]

17. Nayebossadri, S. Kinetic rate-limiting steps in dehydrogenation of $\mathrm{Li}-\mathrm{N}-\mathrm{H}$ and $\mathrm{Li}-\mathrm{Mg}-\mathrm{N}-\mathrm{H}$ systems-effects of elemental Si and Al. Int. J. Hydrogen Energy 2011, 36, 8335-8343. [CrossRef]

18. Isobe, S.; Ichikawa, T.; Hanada, N.; Leng, H.Y.; Fichtner, M.; Fuhr, O.; Fujii, H. Effect of Ti catalyst with different chemical form on Li-N-H hydrogen storage properties. J. Alloys Compd. 2005, 404-406, 439-442. [CrossRef]

19. Nayebossadri, S.; Aguey-Zinsou, K.F.; Guo, Z.X. Effect of nitride additives on Li-N-H hydrogen storage system. Int. J. Hydrogen Energy 2011, 36, 7920-7926. [CrossRef]

20. Sale, M.; Pistidda, C.; Taras, A.; Napolitano, E.; Milanese, C.; Karimi, F.; Dornheim, M.; Garroni, S.; Enzo, S.; Mulas, G. In situ synchrotron radiation powder X-ray diffraction study of the $2 \mathrm{LiNH}_{2}+\mathrm{LiH}+\mathrm{KBH}_{4}$ system. J. Alloys Compd. 2013, 580 (Suppl. 1), S278-S281. [CrossRef]

21. Yao, J.H.; Shang, C.; Aguey-Zinsou, K.F.; Guo, Z.X. Desorption characteristics of mechanically and chemically modified $\mathrm{LiNH}_{2}$ and $\left(\mathrm{LiNH}_{2}+\mathrm{LiH}\right)$. J. Alloys Compd. 2007, 432, 277-282. [CrossRef]

22. David, W.I.F.; Jones, M.O.; Gregory, D.H.; Jewell, C.M.; Johnson, S.R.; Walton, A.; Edwards, P.P. A Mechanism for Non-stoichiometry in the Lithium Amide/Lithium Imide Hydrogen Storage Reaction. J. Am. Chem. Soc. 2007, 129, 1594-1601. [CrossRef] [PubMed]

23. Pistidda, C.; Santoru, A.; Garroni, S.; Bergemann, N.; Rzeszutek, A.; Horstmann, C.; Thomas, D.; Klassen, T.; Dornheim, M. First Direct Study of the Ammonolysis Reaction in the Most Common Alkaline and Alkaline Earth Metal Hydrides by in Situ SR-PXD. J. Phys. Chem. C 2015, 119, 934-943. [CrossRef] 
24. Makepeace, J.W.; Jones, M.O.; Callear, S.K.; Edwards, P.P.; David, W.I. In situ X-ray powder diffraction studies of hydrogen storage and release in the Li-N-H system. Phys. Chem. Chem. Phys. 2014, 16, 4061-4070. [CrossRef] [PubMed]

25. Anderson, P.A.; Chater, P.A.; Hewett, D.R.; Slater, P.R. Hydrogen storage and ionic mobility in amide-halide systems. Faraday Discuss. 2011, 151, 271-284. [CrossRef] [PubMed]

26. Matsuo, M.; Sato, T.; Miura, Y.; Oguchi, H.; Zhou, Y.; Maekawa, H.; Takamura, H.; Orimo, S.-I. Synthesis and lithium fast-ion conductivity of a new complex hydride $\mathrm{Li}_{3}\left(\mathrm{NH}_{2}\right)_{2} \mathrm{I}$ with double-layered structure. Chem. Mater. 2010, 22, 2702-2704. [CrossRef]

27. Howard, M.A.; Clemens, O.; Slater, P.R.; Anderson, P.A. Hydrogen absorption and lithium ion conductivity in $\mathrm{Li}_{6} \mathrm{NBr}_{3}$. J. Alloys Compd. 2015, 645 (Suppl. 1), S174-S177. [CrossRef]

28. Nguyen, T.T.T.; Reed, D.; Book, D.; Anderson, P.A. Hydrogen release and uptake in the Li-Zn-N system. J. Alloys Compd. 2015, 645 (Suppl. 1), S295-S298. [CrossRef]

29. Davies, R.A.; Hewett, D.R.; Anderson, P.A. Enhancing ionic conductivity in lithium amide for improved energy storage materials. Adv. Nat. Sci. Nanosci. Nanotechnol. 2015, 6, 015005.

30. Davies, R.A.; Anderson, P.A. Synthesis and characterization of two new amide chloride compounds: Potential $\mathrm{H}_{2}$ storage materials. Int. J. Hydrogen Energy 2015, 40, 3001-3005. [CrossRef]

31. Cao, H.; Wang, J.; Chua, Y.; Wang, H.; Wu, G.; Xiong, Z.; Qiu, J.; Chen, P. $\mathrm{NH}_{3}$ Mediated or Ion Migration Reaction: The Case Study on Halide-Amide System. J. Phys. Chem. C 2014, 118, 2344-2349. [CrossRef]

32. Leng, H.; Wu, Z.; Duan, W.; Xia, G.; Li, Z. Effect of $\mathrm{MgCl}_{2}$ additives on the H-desorption properties of Li-N-H system. Int. J. Hydrogen Energy 2012, 37, 903-907. [CrossRef]

33. Fernández Albanesi, L.; Arneodo Larochette, P.; Gennari, F.C. Destabilization of the $\mathrm{LiNH}_{2}-\mathrm{LiH}_{\mathrm{H}}$ hydrogen storage system by aluminum incorporation. Int. J. Hydrogen Energy 2013, 38, 12325-12334. [CrossRef]

34. Fernández Albanesi, L.; Garroni, S.; Arneodo Larochette, P.; Nolis, P.; Mulas, G.; Enzo, S.; Baró, M.D.; Gennari, F.C. Role of aluminum chloride on the reversible hydrogen storage properties of the $\mathrm{Li}-\mathrm{N}-\mathrm{H}$ system. Int. J. Hydrogen Energy 2015, 40, 13506-13517. [CrossRef]

35. Fernandez Albanesi, L.; Garroni, S.; Enzo, S.; Gennari, F.C. New amide-chloride phases in the Li-Al-N-H-Cl system: Formation and hydrogen storage behaviour. Dalton Trans. 2016, 45, 5808-5814. [CrossRef] [PubMed]

36. Dong, B.-X.; Gao, J.-J.; Tian, H.; Teng, Y.-L.; Wang, L.-Z.; Liu, W.-L. Hydrogen desorption improvement of the $\mathrm{LiNH}_{2}-\mathrm{LiH}-\mathrm{KF}$ composite. Int. J. Hydrogen Energy 2016, 41, 16122-16128. [CrossRef]

37. Zhang, W.; Wang, H.; Cao, H.; He, T.; Guo, J.; Wu, G.; Chen, P. Effects of doping $\mathrm{FeCl}_{3}$ on hydrogen storage properties of Li-N-H system. Prog. Nat. Sci. Mater. Int. 2017, 27, 139-143. [CrossRef]

38. Amica, G.; Larochette, P.A.; Gennari, F. Hydrogen storage properties of $\mathrm{LiNH}_{2}-\mathrm{LiH}$ system with $\mathrm{MgH}_{2}$, $\mathrm{CaH}_{2}$ and $\mathrm{TiH}_{2}$ added. Int. J. Hydrogen Energy 2015, 40, 9335-9346. [CrossRef]

39. Lin, H.-J.; Li, H.-W.; Murakami, H.; Akiba, E. Remarkably improved hydrogen storage properties of $\mathrm{LiNH}_{2}-\mathrm{LiH}$ composite via the addition of $\mathrm{CeF}_{4}$. J. Alloys Compd. 2018, 735, 1017-1022. [CrossRef]

40. Chu, H.; Xiong, Z.; Wu, G.; He, T.; Wu, C.; Chen, P. Hydrogen storage properties of Li-Ca-N-H system with different molar ratios of $\mathrm{LiNH}_{2} / \mathrm{CaH}_{2}$. Int. J. Hydrogen Energy 2010, 35, 8317-8321. [CrossRef]

41. Meisner, G.P.; Scullin, M.L.; Balogh, M.P.; Pinkerton, F.E.; Meyer, M.S. Hydrogen Release from Mixtures of Lithium Borohydride and Lithium Amide: A Phase Diagram Study. J. Phys. Chem. B 2006, 110, 4186-4192. [CrossRef] [PubMed]

42. Nakamori, Y.; Ninomiya, A.; Kitahara, G.; Aoki, M.; Noritake, T.; Miwa, K.; Kojima, Y.; Orimo, S. Dehydriding reactions of mixed complex hydrides. J. Power Sources 2006, 155, 447-455. [CrossRef]

43. Tokoyoda, K.; Hino, S.; Ichikawa, T.; Okamoto, K.; Fujii, H. Hydrogen desorption/absorption properties of Li-Ca-N-H system. J. Alloys Compd. 2007, 439, 337-341. [CrossRef]

44. Xiong, Z.; Wu, G.; Hu, J.; Chen, P. Investigation on chemical reaction between $\mathrm{LiAlH}_{4}$ and $\mathrm{LiNH}_{2}$. J. Power Sources 2006, 159, 167-170. [CrossRef]

45. Zhang, Y.; Liu, Y.; Yang, Y.; Li, Y.; Hu, J.; Gao, M.; Pan, H. Superior catalytic activity of in situ reduced metallic Co for hydrogen storage in a $\mathrm{Co}(\mathrm{OH})_{2}$-containing $\mathrm{LiBH}_{4} / 2 \mathrm{LiNH}_{2}$ composite. Mater. Res. Bull. 2018, 97, 544-552. [CrossRef]

46. Chu, H.; Xiong, Z.; Wu, G.; Guo, J.; He, T.; Chen, P. Improved dehydrogenation properties of Ca( $\left.\mathrm{BH}_{4}\right)_{2}-\mathrm{LiNH}_{2}$ combined system. Dalton Trans. 2010, 39, 10585-10587. [CrossRef] [PubMed]

47. Makepeace, J.W.; David, W.I.F. Structural Insights into the Lithium Amide-Imide Solid Solution. J. Phys. Chem. C 2017, 121, 12010-12017. [CrossRef] 
48. Leng, H.Y.; Ichikawa, T.; Hino, S.; Hanada, N.; Isobe, S.; Fujii, H. New Metal-N-H System Composed of $\mathrm{Mg}\left(\mathrm{NH}_{2}\right)_{2}$ and $\mathrm{LiH}$ for Hydrogen Storage. J. Phys. Chem. B 2004, 108, 8763-8765. [CrossRef]

49. Nakamori, Y.; Kitahara, G.; Orimo, S. Synthesis and dehydriding studies of Mg-N-H systems. J. Power Sources 2004, 138, 309-312. [CrossRef]

50. Orimo, S.; Nakamori, Y.; Kitahara, G.; Miwa, K.; Ohba, N.; Noritake, T.; Towata, S. Destabilization and enhanced dehydriding reaction of $\mathrm{LiNH}_{2}$ : An electronic structure viewpoint. Appl. Phys. A 2004, 79, 1765-1767. [CrossRef]

51. Luo, W. ( $\mathrm{LiNH}_{2}-\mathrm{MgH}_{2}$ ): A viable hydrogen storage system. J. Alloys Compd. 2004, 381, 284-287. [CrossRef]

52. Xiong, Z.T.; Wu, G.T.; Hu, H.J.; Chen, P. Ternary imides for hydrogen storage. Adv. Mater. 2004, 16, 1522-1525. [CrossRef]

53. Chen, Y.; Wu, C.-Z.; Wang, P.; Cheng, H.-M. Structure and hydrogen storage property of ball-milled $\mathrm{LiNH}_{2} / \mathrm{MgH}_{2}$ mixture. Int. J. Hydrogen Energy 2006, 31, 1236-1240. [CrossRef]

54. Luo, W.; Sickafoose, S. Thermodynamic and structural characterization of the $\mathrm{Mg}-\mathrm{Li}-\mathrm{N}-\mathrm{H}$ hydrogen storage system. J. Alloys Compd. 2006, 407, 274-281. [CrossRef]

55. Luo, W.; Stewart, K. Characterization of $\mathrm{NH}_{3}$ formation in desorption of $\mathrm{Li}-\mathrm{Mg}-\mathrm{N}-\mathrm{H}$ storage system. J. Alloys Compd. 2007, 440, 357-361. [CrossRef]

56. Luo, W.; Wang, J.; Stewart, K.; Clift, M.; Gross, K. Li-Mg-N-H: Recent investigations and development. J. Alloys Compd. 2007, 446-447, 336-341. [CrossRef]

57. Markmaitree, T.; Osborn, W.; Shaw, L.L. Comparisons between $\mathrm{MgH}_{2}$-and LiH-containing systems for hydrogen storage applications. Int. J. Hydrogen Energy 2008, 33, 3915-3924. [CrossRef]

58. Leng, H.; Ichikawa, T.; Hino, S.; Hanada, N.; Isobe, S.; Fujii, H. Synthesis and decomposition reactions of metal amides in metal-N-H hydrogen storage system. J. Power Sources 2006, 156, 166-170. [CrossRef]

59. Dolci, F.; Napolitano, E.; Weidner, E.; Enzo, S.; Moretto, P.; Brunelli, M.; Hansen, T.; Fichtner, M.; Lohstroh, W. Magnesium imide: Synthesis and structure determination of an unconventional alkaline earth imide from decomposition of magnesium amide. Inorg. Chem. 2010, 50, 1116-1122. [CrossRef] [PubMed]

60. Rijssenbeek, J.; Gao, Y.; Hanson, J.; Huang, Q.; Jones, C.; Toby, B. Crystal structure determination and reaction pathway of amide-hydride mixtures. J. Alloys Compd. 2008, 454, 233-244. [CrossRef]

61. Yang, J.; Sudik, A.; Wolverton, C. Activation of hydrogen storage materials in the Li-Mg-N-H system: Effect on storage properties. J. Alloys Compd. 2007, 430, 334-338. [CrossRef]

62. Anton, D.L.; Price, C.J.; Gray, J. Affects of Mechanical Milling and Metal Oxide Additives on Sorption Kinetics of 1:1 $\mathrm{LiNH}_{2} / \mathrm{MgH}_{2}$ Mixture. Energies 2011, 4, 826-844. [CrossRef]

63. Bill, R.F.; Reed, D.; Book, D.; Anderson, P.A. Effect of the calcium halides, $\mathrm{CaCl}_{2}$ and $\mathrm{CaBr}_{2}$, on hydrogen desorption in the Li-Mg-N-H system. J. Alloys Compd. 2015, 645, S96-S99. [CrossRef]

64. Demirocak, D.E.; Srinivasan, S.S.; Ram, M.K.; Kuhn, J.N.; Muralidharan, R.; Li, X.; Goswami, D.Y.; Stefanakos, E.K. Reversible hydrogen storage in the Li-Mg-N-H system-The effects of Ru doped single walled carbon nanotubes on $\mathrm{NH}_{3}$ emission and kinetics. Int. J. Hydrogen Energy 2013, 38, 10039-10049. [CrossRef]

65. Durojaiye, T.; Hayes, J.; Goudy, A. Rubidium hydride: An exceptional dehydrogenation catalyst for the lithium amide/magnesium hydride system. J. Phys. Chem. C 2013, 117, 6554-6560. [CrossRef]

66. Durojaiye, T.; Hayes, J.; Goudy, A. Potassium, rubidium and cesium hydrides as dehydrogenation catalysts for the lithium amide/magnesium hydride system. Int. J. Hydrogen Energy 2015, 40, 2266-2273. [CrossRef]

67. Hayes, J.; Durojaiye, T.; Goudy, A. Hydriding and dehydriding kinetics of RbH-doped $2 \mathrm{LiNH}_{2} / \mathrm{MgH}_{2}$ hydrogen storage system. J. Alloys Compd. 2015, 645 (Suppl. 1), S496-S499. [CrossRef]

68. Miyaoka, H.; Wang, Y.; Hino, S.; Isobe, S.; Tokoyoda, K.; Ichikawa, T.; Kojima, Y. Kinetic Modification on Hydrogen Desorption of Lithium Hydride and Magnesium Amide System. Materials 2015, 8, 3896-3909. [CrossRef] [PubMed]

69. Price, C.; Gray, J.; Lascola Jr, R.; Anton, D.L. The effects of halide modifiers on the sorption kinetics of the Li-Mg-N-H System. Int. J. Hydrogen Energy 2012, 37, 2742-2749. [CrossRef]

70. Sun, F.; Yan, M.-Y.; Ye, J.-H.; Liu, X.-P.; Jiang, L.-J. Effect of CO on hydrogen storage performance of KF doped 2LiNH ${ }_{2}+\mathrm{MgH}_{2}$ material. J. Alloys Compd. 2014, 616, 47-50. [CrossRef]

71. Ulmer, U.; Hu, J.; Franzreb, M.; Fichtner, M. Preparation, scale-up and testing of nanoscale, doped amide systems for hydrogen storage. Int. J. Hydrogen Energy 2013, 38, 1439-1449. [CrossRef] 
72. Yan, M.Y.; Sun, F.; Liu, X.P.; Ye, J.H.; Yuan, H.P.; Wang, S.M.; Jiang, L.J. Experimental study on hydrogen storage properties of Li-Mg-N-H based tank. J. Alloys Compd. 2014, 603, 19-22. [CrossRef]

73. Luo, W.; Stavila, V.; Klebanoff, L.E. New insights into the mechanism of activation and hydrogen absorption of $\left(2 \mathrm{LiNH}_{2}-\mathrm{MgH}_{2}\right)$. Int. J. Hydrogen Energy 2012, 37, 6646-6652. [CrossRef]

74. Durojaiye, T.; Goudy, A. Desorption kinetics of lithium amide/magnesium hydride systems at constant pressure thermodynamic driving forces. Int. J. Hydrogen Energy 2012, 37, 3298-3304. [CrossRef]

75. Yang, J.; Sudik, A.; Siegel, D.J.; Halliday, D.; Drews, A.; Carter, R.O.; Wolverton, C.; Lewis, G.J.; Sachtler, J.W.A.; Low, J.J.; et al. Hydrogen storage properties of $2 \mathrm{LiNH}_{2}+\mathrm{LiBH}_{4}+\mathrm{MgH}_{2}$. J. Alloys Compd. 2007, 446-447, 345-349. [CrossRef]

76. Sudik, A.; Yang, J.; Halliday, D.; Wolverton, C. Hydrogen Storage Properties in $\left(\mathrm{LiNH}_{2}\right)_{2}-\mathrm{LiBH}_{4}-\left(\mathrm{MgH}_{2}\right) \mathrm{X}$ Mixtures (X=0.0-1.0). J. Phys. Chem. C 2008, 112, 4384-4390. [CrossRef]

77. Parviz, R.; Varin, R. Combined effects of molar ratio and ball milling energy on the phase transformations and mechanical dehydrogenation in the lithium amide-magnesium hydride $\left(\mathrm{LiNH}_{2}+\mathrm{nMgH}_{2}\right)(\mathrm{n}=0.5-2.0)$ nanocomposites. Int. J. Hydrogen Energy 2013, 38, 8313-8327. [CrossRef]

78. Varin, R.; Parviz, R.; Polanski, M.; Wronski, Z. The effect of milling energy input and molar ratio on the dehydrogenation and thermal conductivity of the $\left(\mathrm{LiNH}_{2}+\mathrm{nMgH}_{2}\right)(\mathrm{n}=0.5,0.7,0.9,1.0,1.5$ and 2.0) nanocomposites. Int. J. Hydrogen Energy 2014, 39, 10585-10599. [CrossRef]

79. Xiong, Z.; Hu, J.; Wu, G.; Chen, P.; Luo, W.; Gross, K.; Wang, J. Thermodynamic and kinetic investigations of the hydrogen storage in the Li-Mg-N-H system. J. Alloys Compd. 2005, 398, 235-239. [CrossRef]

80. Xiong, Z.; Wu, G.; Hu, J.; Chen, P.; Luo, W.; Wang, J. Investigations on hydrogen storage over Li-Mg-N-H complex-The effect of compositional changes. J. Alloys Compd. 2006, 417, 190-194. [CrossRef]

81. Aoki, M.; Noritake, T.; Kitahara, G.; Nakamori, Y.; Towata, S.; Orimo, S. Dehydriding reaction of $\mathrm{Mg}\left(\mathrm{NH}_{2}\right)_{2}-\mathrm{LiH}$ system under hydrogen pressure. J. Alloys Compd. 2007, 428, 307-311. [CrossRef]

82. Hu, J.; Fichtner, M. Formation and stability of ternary imides in the $\mathrm{Li}-\mathrm{Mg}-\mathrm{N}-\mathrm{H}$ hydrogen storage system. Chem. Mater. 2009, 21, 3485-3490. [CrossRef]

83. Ikeda, S.; Tokoyoda, K.; Kiyobayashi, T.; Kuriyama, N. Cyclic properties and ammonia by-product emission of $\mathrm{Li} / \mathrm{Mg}-\mathrm{N}-\mathrm{H}$ hydrogen storage material. Int. J. Hydrogen Energy 2011, 36, 8373-8380. [CrossRef]

84. Cao, H.; Chua, Y.; Zhang, Y.; Xiong, Z.; Wu, G.; Qiu, J.; Chen, P. Releasing 9.6 wt\% of $\mathrm{H}_{2}$ from $\mathrm{Mg}\left(\mathrm{NH}_{2}\right)_{2}-3 \mathrm{LiH}-\mathrm{NH}_{3} \mathrm{BH}_{3}$ through mechanochemical reaction. Int. J. Hydrogen Energy 2013, 38, 10446-10452. [CrossRef]

85. Liu, Y.; Hu, J.; Xiong, Z.; Wu, G.; Chen, P. Improvement of the hydrogen-storage performances of Li-Mg-N-H system. J. Mater. Res. 2007, 22, 1339-1345. [CrossRef]

86. Sudik, A.; Yang, J.; Halliday, D.; Wolverton, C. Kinetic Improvement in the $\mathrm{Mg}\left(\mathrm{NH}_{2}\right)_{2}-\mathrm{LiH}$ Storage System by Product Seeding. J. Phys. Chem. C 2007, 111, 6568-6573. [CrossRef]

87. Liu, Y.; Zhong, K.; Luo, K.; Gao, M.; Pan, H.; Wang, Q. Size-Dependent Kinetic Enhancement in Hydrogen Absorption and Desorption of the Li-Mg-N-H System. J. Am. Chem. Soc. 2009, 131, 1862-1870. [CrossRef] [PubMed]

88. Janot, R.; Eymery, J.-B.; Tarascon, J.-M. Investigation of the processes for reversible hydrogen storage in the Li-Mg-N-H system. J. Power Sources 2007, 164, 496-502. [CrossRef]

89. Li, C.; Liu, Y.; Ma, R.; Zhang, X.; Li, Y.; Gao, M.; Pan, H. Superior Dehydrogenation/Hydrogenation Kinetics and Long-Term Cycling Performance of $\mathrm{K}$ and $\mathrm{Rb}$ Cocatalyzed $\mathrm{Mg}\left(\mathrm{NH}_{2}\right)_{2}-2 \mathrm{LiH}$ system. ACS Appl. Mater. Interfaces 2014, 6, 17024-17033. [CrossRef] [PubMed]

90. Liang, C.; Liu, Y.; Wei, Z.; Jiang, Y.; Wu, F.; Gao, M.; Pan, H. Enhanced dehydrogenation/hydrogenation kinetics of the $\mathrm{Mg}\left(\mathrm{NH}_{2}\right)_{2}-2 \mathrm{LiH}$ system with $\mathrm{NaOH}$ additive. Int. J. Hydrogen Energy 2011, 36, 2137-2144. [CrossRef]

91. Ma, L.-P.; Dai, H.-B.; Liang, Y.; Kang, X.-D.; Fang, Z.-Z.; Wang, P.-J.; Wang, P.; Cheng, H.-M. Catalytically enhanced hydrogen storage properties of $\mathrm{Mg}\left(\mathrm{NH}_{2}\right)_{2}+2 \mathrm{LiH}$ material by graphite-supported Ru nanoparticles. J. Phys. Chem. C 2008, 112, 18280-18285. [CrossRef]

92. Shahi, R.R.; Yadav, T.; Shaz, M.; Srivastva, O. Studies on dehydrogenation characteristic of $\mathrm{Mg}\left(\mathrm{NH}_{2}\right)_{2} / \mathrm{LiH}$ mixture admixed with vanadium and vanadium based catalysts $\left(\mathrm{V}, \mathrm{V}_{2} \mathrm{O}_{5}\right.$ and $\left.\mathrm{VCl}_{3}\right)$. Int. J. Hydrogen Energy 2010, 35, 238-246. [CrossRef] 
93. Wang, J.; Liu, T.; Wu, G.; Li, W.; Liu, Y.; Araújo, C.M.; Scheicher, R.H.; Blomqvist, A.; Ahuja, R.; Xiong, Z.; et al. Potassium-Modified $\mathrm{Mg}\left(\mathrm{NH}_{2}\right)_{2} / 2 \mathrm{LiH}$ System for Hydrogen Storage. Angew. Chem. Int. Ed. 2009, 48, 5828-5832. [CrossRef] [PubMed]

94. Yan, M.-Y.; Sun, F.; Liu, X.-P.; Ye, J.-H. Effects of compaction pressure and graphite content on hydrogen storage properties of $\mathrm{Mg}\left(\mathrm{NH}_{2}\right)_{2}-2 \mathrm{LiH}$ hydride. Int. J. Hydrogen Energy 2014, 39, 19656-19661. [CrossRef]

95. Torre, F.; Valentoni, A.; Milanese, C.; Pistidda, C.; Marini, A.; Dornheim, M.; Enzo, S.; Mulas, G.; Garroni, S. Kinetic improvement on the $\mathrm{CaH}_{2}$-catalyzed $\mathrm{Mg}\left(\mathrm{NH}_{2}\right)_{2}+2 \mathrm{LiH}$ system. J. Alloys Compd. 2015, 645, S284-S287. [CrossRef]

96. Hu, J.; Liu, Y.; Wu, G.; Xiong, Z.; Chua, Y.S.; Chen, P. Improvement of Hydrogen Storage Properties of the $\mathrm{Li}-\mathrm{Mg}-\mathrm{N}-\mathrm{H}$ System by Addition of $\mathrm{LiBH}_{4}$. Chem. Mater. 2008, 20, 4398-4402. [CrossRef]

97. Napolitano, E.; Dolci, F.; Campesi, R.; Pistidda, C.; Hoelzel, M.; Moretto, P.; Enzo, S. Crystal structure solution of $\mathrm{KMg}(\mathrm{ND})\left(\mathrm{ND}_{2}\right)$ : An ordered mixed amide/imide compound. Int. J. Hydrogen Energy 2014, 39, 868-876. [CrossRef]

98. Santoru, A.; Garroni, S.; Pistidda, C.; Milanese, C.; Girella, A.; Marini, A.; Masolo, E.; Valentoni, A.; Bergemann, N.; Le, T.T.; et al. A new potassium-based intermediate and its role in the desorption properties of the K-Mg-N-H system. Phys. Chem. Chem. Phys. 2016, 18, 3910-3920. [CrossRef] [PubMed]

99. Santoru, A.; Pistidda, C.; Sorby, M.H.; Chierotti, M.R.; Garroni, S.; Pinatel, E.; Karimi, F.; Cao, H.; Bergemann, N.; Le, T.T.; et al. $\mathrm{KNH}_{2}-\mathrm{KH}$ : A metal amide-hydride solid solution. Chem. Commun. 2016, 52, 11760-11763. [CrossRef] [PubMed]

100. Wang, J.; Chen, P.; Pan, H.; Xiong, Z.; Gao, M.; Wu, G.; Liang, C.; Li, C.; Li, B.; Wang, J. Solid-Solid Heterogeneous Catalysis: The Role of Potassium in Promoting the Dehydrogenation of the $\mathrm{Mg}\left(\mathrm{NH}_{2}\right)_{2} / 2 \mathrm{LiH}$ Composite. ChemSusChem 2013, 6, 2181-2189. [CrossRef] [PubMed]

101. Wang, J.; Wu, G.; Chua, Y.S.; Guo, J.; Xiong, Z.; Zhang, Y.; Gao, M.; Pan, H.; Chen, P. Hydrogen Sorption from the $\mathrm{Mg}\left(\mathrm{NH}_{2}\right)_{2}-\mathrm{KH}$ System and Synthesis of an Amide-Imide Complex of $\mathrm{KMg}(\mathrm{NH})\left(\mathrm{NH}_{2}\right)$. ChemSusChem 2011, 4, 1622-1628. [CrossRef] [PubMed]

102. Li, C.; Liu, Y.; Yang, Y.; Gao, M.; Pan, H. High-temperature failure behaviour and mechanism of K-based additives in Li-Mg-N-H hydrogen storage systems. J. Mater. Chem. A 2014, 2, 7345-7353. [CrossRef]

103. Liang, C.; Liu, Y.; Gao, M.; Pan, H. Understanding the role of $\mathrm{K}$ in the significantly improved hydrogen storage properties of a KOH-doped Li-Mg-N-H system. J. Mater. Chem. A 2013, 1, 5031-5036. [CrossRef]

104. Liu, Y.; Li, C.; Li, B.; Gao, M.; Pan, H. Metathesis Reaction-Induced Significant Improvement in Hydrogen Storage Properties of the KF-Added $\mathrm{Mg}\left(\mathrm{NH}_{2}\right)_{2}-2 \mathrm{LiH}$ System. J. Phys. Chem. C 2013, 117, 866-875. [CrossRef]

105. Liu, Y.; Yang, Y.; Zhang, X.; Li, Y.; Gao, M.; Pan, H. Insights into the dehydrogenation reaction process of a K-containing $\mathrm{Mg}\left(\mathrm{NH}_{2}\right)_{2}-2 \mathrm{LiH}$ system. Dalton Trans. 2015, 44, 18012-18018. [CrossRef] [PubMed]

106. Lin, H.-J.; Li, H.-W.; Paik, B.; Wang, J.; Akiba, E. Improvement of hydrogen storage property of three-component $\mathrm{Mg}\left(\mathrm{NH}_{2}\right)_{2}-\mathrm{LiNH}_{2}-\mathrm{LiH}$ composites by additives. Dalton Trans. 2016, 45, 15374-15381. [CrossRef] [PubMed]

107. Li, C.; Liu, Y.; Gu, Y.; Gao, M.; Pan, H. Improved Hydrogen-Storage Thermodynamics and Kinetics for an RbF-Doped $\mathrm{Mg}\left(\mathrm{NH}_{2}\right)_{2}-2 \mathrm{LiH}$ System. Chem. Asian J. 2013, 8, 2136-2143. [CrossRef] [PubMed]

108. Santoru, A.; Pistidda, C.; Brighi, M.; Chierotti, M.R.; Heere, M.; Karimi, F.; Cao, H.; Capurso, G.; Chaudhary, A.-L.; Gizer, G.; et al. Insights into the Rb-Mg-N-H System: An Ordered Mixed Amide/Imide Phase and a Disordered Amide/Hydride Solid Solution. Inorg. Chem. 2018, 57, 3197-3205. [CrossRef] [PubMed]

109. Zhang, J.; Liu, Y.; Zhang, X.; Yang, Y.; Zhang, Q.; Jin, T.; Wang, Y.; Gao, M.; Sun, L.; Pan, H. Synthesis of CsH and its effect on the hydrogen storage properties of the $\mathrm{Mg}\left(\mathrm{NH}_{2}\right)_{2}-2 \mathrm{LiH}$ system. Int. J. Hydrogen Energy 2016, 41, 11264-11274. [CrossRef]

110. Zhang, J.; Wang, Y.; Zhang, M.; Leng, Z.; Gao, M.; Hu, J.; Liu, Y.; Pan, H. Improved overall hydrogen storage properties of a $\mathrm{CsH}$ and $\mathrm{KH}$ co-doped $\mathrm{Mg}\left(\mathrm{NH}_{2}\right)_{2} / 2 \mathrm{LiH}$ system by forming mixed amides of $\mathrm{Li}-\mathrm{K}$ and Cs-Mg. RSC Adv. 2017, 7, 30357-30364. [CrossRef]

111. Xia, G.; Chen, X.; Zhao, Y.; Li, X.; Guo, Z.; Jensen, C.M.; Gu, Q.; Yu, X. High-Performance Hydrogen Storage Nanoparticles Inside Hierarchical Porous Carbon Nanofibers with Stable Cycling. ACS Appl. Mater. Interfaces 2017, 9, 15502-15509. [CrossRef] [PubMed]

112. Vajo, J.J.; Skeith, S.L.; Mertens, F. Reversible Storage of Hydrogen in Destabilized LiBH 4 . J. Phys. Chem. B 2005, 109, 3719-3722. [CrossRef] [PubMed] 
113. Filinchuk, Y.E.; Yvon, K.; Meisner, G.P.; Pinkerton, F.E.; Balogh, M.P. On the Composition and Crystal Structure of the New Quaternary Hydride Phase $\mathrm{Li}_{4} \mathrm{BN}_{3} \mathrm{H}_{10}$. Inorg. Chem. 2006, 45, 1433-1435. [CrossRef] [PubMed]

114. Lewis, G.J.; Sachtler, J.W.A.; Low, J.J.; Lesch, D.A.; Faheem, S.A.; Dosek, P.M.; Knight, L.M.; Halloran, L.; Jensen, C.M.; Yang, J.; et al. High throughput screening of the ternary $\mathrm{LiNH}_{2}-\mathrm{MgH}_{2}-\mathrm{LiBH}_{4}$ phase diagram. J. Alloys Compd. 2007, 446-447, 355-359. [CrossRef]

115. Sudik, A.; Yang, J.; Siegel, D.J.; Wolverton, C.; Carter, R.O.; Drews, A.R. Impact of Stoichiometry on the Hydrogen Storage Properties of $\mathrm{LiNH}_{2}-\mathrm{LiBH}_{4}-\mathrm{MgH}_{2}$ Ternary Composites. J. Phys. Chem. C 2009, 113, 2004-2013. [CrossRef]

116. Yang, J.; Sudik, A.; Siegel, D.J.; Halliday, D.; Drews, A.; Carter, R.O.; Wolverton, C.; Lewis, G.J.; Sachtler, J.W.A.; Low, J.J.; et al. A Self-Catalyzing Hydrogen-Storage Material. Angew. Chem. Int. Ed. 2008, 47, 882-887. [CrossRef] [PubMed]

117. Hu, J.; Fichtner, M.; Chen, P. Investigation on the Properties of the Mixture Consisting of $\mathrm{Mg}\left(\mathrm{NH}_{2}\right)_{2}, \mathrm{LiH}$, and $\mathrm{LiBH}_{4}$ as a Hydrogen Storage Material. Chem. Mater. 2008, 20, 7089-7094. [CrossRef]

118. Hu, J.; Weidner, E.; Hoelzel, M.; Fichtner, M. Functions of $\mathrm{LiBH}_{4}$ in the hydrogen sorption reactions of the 2LiH-Mg( $\left.\mathrm{NH}_{2}\right)_{2}$ system. Dalton Trans. 2010, 39, 9100-9107. [CrossRef] [PubMed]

119. Cao, H.J.; Wu, G.T.; Zhang, Y.; Xiong, Z.T.; Qiu, J.S.; Chen, P. Effective thermodynamic alteration to $\mathrm{Mg}\left(\mathrm{NH}_{2}\right)_{2}$-LiH system: Achieving near ambient-temperature hydrogen storage. J. Mater. Chem. A 2014, 2, 15816-15822. [CrossRef]

120. Wang, H.; Cao, H.J.; Wu, G.T.; He, T.; Chen, P. The improved Hydrogen Storage Performances of the Multi-Component Composite: $2 \mathrm{Mg}\left(\mathrm{NH}_{2}\right)_{2}-3 \mathrm{LiH}-\mathrm{LiBH}_{4}$. Energies 2015, 8, 6898-6909. [CrossRef]

121. Wang, H.; Cao, H.J.; Pistidda, C.; Garroni, S.; Wu, G.T.; Klassen, T.; Dorheim, M.; Chen, P. Effects of Stoichiometry on the H-2-Storage Properties of $\mathrm{Mg}\left(\mathrm{NH}_{2}\right)_{2}-\mathrm{LiH}_{-} \mathrm{LiBH}_{4}$ Tri-Component Systems. Chem. Asian J. 2017, 12, 1758-1764. [CrossRef] [PubMed]

122. Wang, H.; Wu, G.T.; Cao, H.J.; Pistidda, C.; Chaudhary, A.L.; Garroni, S.; Dornheim, M.; Chen, P. Near Ambient Condition Hydrogen Storage in a Synergized Tricomponent Hydride System. Adv. Energy Mater. 2017, 7. [CrossRef]

123. Wang, H.; Cao, H.; Zhang, W.; Chen, J.; Wu, H.; Pistidda, C.; Ju, X.; Zhou, W.; Wu, G.; Etter, M.; et al. $\mathrm{Li}_{2} \mathrm{NH}-\mathrm{LiBH}_{4}$ : A Complex Hydride with Near Ambient Hydrogen Adsorption and Fast Lithium Ion Conduction. Chem. Eur. J. 2018, 24, 1342-1347. [CrossRef] [PubMed]

124. Wolczyk, A.; Paik, B.; Sato, T.; Nervi, C.; Brighi, M.; GharibDoust, S.P.; Chierotti, M.; Matsuo, M.; Li, G.; Gobetto, R.; et al. $\mathrm{Li}_{5}\left(\mathrm{BH}_{4}\right) 3 \mathrm{NH}$ : Lithium-Rich Mixed Anion Complex Hydride. J. Phys. Chem. C 2017, 121, 11069-11075. [CrossRef]

125. Zhan, L.; Zhang, Y.; Zhuang, X.; Fang, H.; Zhu, Y.; Guo, X.; Chen, J.; Wang, Z.; Li, L. Ionic conductivities of lithium borohydride-lithium nitride composites. Solid State Ion. 2017, 304, 150-155. [CrossRef]

126. Chen, P.; Xiong, Z.T.; Yang, L.F.; Wu, G.T.; Luo, W.F. Mechanistic investigations on the heterogeneous solid-state reaction of magnesium amides and lithium hydrides. J. Phys. Chem. B 2006, 110, 14221-14225. [CrossRef] [PubMed]

127. Cao, H.; Wang, H.; He, T.; Wu, G.; Xiong, Z.; Qiu, J.; Chen, P. Improved kinetics of the $\mathrm{Mg}\left(\mathrm{NH}_{2}\right)_{2}-2 \mathrm{LiH}$ system by addition of lithium halides. RSC Adv. 2014, 4, 32555-32561. [CrossRef]

128. Matsuo, M.; Remhof, A.; Martelli, P.; Caputo, R.; Ernst, M.; Miura, Y.; Sato, T.; Oguchi, H.; Maekawa, H.; Takamura, $\mathrm{H}$; , et al. Complex Hydrides with $\left(\mathrm{BH}_{4}\right)$ - and $\left(\mathrm{NH}_{2}\right)$-Anions as New Lithium Fast-Ion Conductors. J. Am. Chem. Soc. 2009, 131, 16389-16391. [CrossRef] [PubMed]

129. Srinivasan, S.S.; Niemann, M.U.; Hattrick-Simpers, J.R.; McGrath, K.; Sharma, P.C.; Goswami, D.Y.; Stefanakos, E.K. Effects of nano additives on hydrogen storage behavior of the multinary complex hydride $\mathrm{LiBH}_{4} / \mathrm{LiNH}_{2} / \mathrm{MgH}_{2}$. Int. J. Hydrogen Energy 2010, 35, 9646-9652. [CrossRef]

130. Zhang, X.; Li, Z.; Lv, F.; Li, H.; Mi, J.; Wang, S.; Liu, X.; Jiang, L. Improved hydrogen storage performance of the $\mathrm{LiNH}_{2}-\mathrm{MgH}_{2}-\mathrm{LiBH}_{4}$ system by addition of ZrCo hydride. Int. J. Hydrogen Energy 2010, 35, 7809-7814. [CrossRef]

131. Hu, J.; Pohl, A.; Wang, S.; Rothe, J.; Fichtner, M. Additive Effects of $\mathrm{LiBH}_{4}$ and $\mathrm{ZrCoH}_{3}$ on the Hydrogen Sorption of the Li-Mg-N-H Hydrogen Storage System. J. Phys. Chem. C 2012, 116, 20246-20253. [CrossRef] 
132. Yuan, H.; Zhang, X.; Li, Z.; Ye, J.; Guo, X.; Wang, S.; Liu, X.; Jiang, L. Influence of metal oxide on $\mathrm{LiBH}_{4} / 2 \mathrm{LiNH}_{2} / \mathrm{MgH}_{2}$ system for hydrogen storage properties. Int. J. Hydrogen Energy 2012, 37, 3292-3297. [CrossRef]

133. Zhao, W.; Jiang, L.; Wu, Y.; Ye, J.; Yuan, B.; Li, Z.; Liu, X.; Wang, S. Improved dehydrogenation cycle performance of the $1.1 \mathrm{MgH}_{2}-2 \mathrm{LiNH}_{2}-0.1 \mathrm{LiBH}_{4}$ system by addition of $\mathrm{LaNi}_{4.5} \mathrm{Mn}_{0.5}$ alloy. J. Rare Earths 2015, 33, 783-790. [CrossRef]

134. Li, Z.-N.; Qiu, H.-C.; Guo, X.-M.; Ye, J.-H.; Wang, S.-M.; Jiang, L.-J.; Du, J.; Cuevas, F. Hydrogen storage properties of $\mathrm{Li}-\mathrm{Mg}-\mathrm{N}-\mathrm{B}-\mathrm{H} / \mathrm{ZrCoH}_{3}$ composite with different ball-milling atmospheres. Rare Metals 2017, 1-7. [CrossRef]

135. Cao, H.; Zhang, W.; Pistidda, C.; Puszkiel, J.; Milanese, C.; Santoru, A.; Karimi, F.; Castro Riglos, M.V.; Gizer, G.; Welter, E.; et al. Kinetic alteration of the $6 \mathrm{Mg}\left(\mathrm{NH}_{2}\right)_{2}-9 \mathrm{LiH}-\mathrm{LiBH}_{4}$ system by co-adding $\mathrm{YCl}_{3}$ and $\mathrm{Li}_{3}$ N. Phys. Chem. Chem. Phys. 2017, 19, 32105-32115. [CrossRef] [PubMed]

136. Bürger, I.; Hu, J.J.; Vitillo, J.G.; Kalantzopoulos, G.N.; Deledda, S.; Fichtner, M.; Baricco, M.; Linder, M. Material properties and empirical rate equations for hydrogen sorption reactions in $2 \mathrm{LiNH}_{2}-1.1 \mathrm{MgH}_{2}-0.1 \mathrm{LiBH}_{4}-3 \mathrm{wt} . \% \mathrm{ZrCoH}_{3}$. Int. J. Hydrogen Energy 2014, 39, 8283-8292. [CrossRef]

137. Bürger, I.; Luetto, C.; Linder, M. Advanced reactor concept for complex hydrides: Hydrogen desorption at fuel cell relevant boundary conditions. Int. J. Hydrogen Energy 2014, 39, 7346-7355. [CrossRef]

138. Baricco, M.; Bang, M.; Fichtner, M.; Hauback, B.; Linder, M.; Luetto, C.; Moretto, P.; Sgroi, M. SSH2S: Hydrogen storage in complex hydrides for an auxiliary power unit based on high temperature proton exchange membrane fuel cells. J. Power Sources 2017, 342, 853-860. [CrossRef]

139. Yang, J.; Li, D.; Fu, H.; Xin, G.; Zheng, J.; Li, X. In situ hybridization of $\mathrm{LiNH}_{2}-\mathrm{LiH}-\mathrm{Mg}\left(\mathrm{BH}_{4}\right)_{2}$ nano-composites: Intermediate and optimized hydrogenation properties. Phys. Chem. Chem. Phys. 2012, 14, 2857-2863. [CrossRef] [PubMed]

140. Pan, H.; Shi, S.; Liu, Y.; Li, B.; Yang, Y.; Gao, M. Improved hydrogen storage kinetics of the Li-Mg-N-H system by addition of $\mathrm{Mg}\left(\mathrm{BH}_{4}\right)_{2}$. Dalton Trans. 2013, 42, 3802-3811. [CrossRef] [PubMed]

141. Qiu, S.; Ma, X.; Wang, E.; Chu, H.; Huot, J.; Zou, Y.; Xiang, C.; Xu, F.; Sun, L. Enhanced hydrogen storage properties of $2 \mathrm{LiNH}_{2} / \mathrm{MgH}_{2}$ through the addition of $\mathrm{Mg}\left(\mathrm{BH}_{4}\right)_{2}$. J. Alloys Compd. 2017, 704, 44-50. [CrossRef]

142. Li, B.; Liu, Y.; Gu, J.; Gu, Y.; Gao, M.; Pan, H. Mechanistic investigations on significantly improved hydrogen storage performance of the $\mathrm{Ca}\left(\mathrm{BH}_{4}\right)_{2}$-added $2 \mathrm{LiNH}_{2} / \mathrm{MgH}_{2}$ system. Int. J. Hydrogen Energy 2013, 38, 5030-5038. [CrossRef]

143. Amica, G.; Cova, F.; Arneodo Larochette, P.; Gennari, F.C. Effective participation of $\mathrm{Li}_{4}\left(\mathrm{NH}_{2}\right) 3 \mathrm{BH}_{4}$ in the dehydrogenation pathway of the $\mathrm{Mg}\left(\mathrm{NH}_{2}\right)_{2}-2 \mathrm{LiH}$ composite. Phys. Chem. Chem. Phys. 2016, 18, 17997-18005. [CrossRef] [PubMed]

144. Amica, G.; Cova, F.; Arneodo Larochette, P.; Gennari, F.C. Two-controlling mechanisms model for hydrogen desorption in the $\mathrm{Li}_{4}\left(\mathrm{NH}_{2}\right) 3 \mathrm{BH}_{4}$ doped $\mathrm{Mg}\left(\mathrm{NH}_{2}\right)_{2}-2 \mathrm{LiH}$ system. Int. J. Hydrogen Energy 2017, 42, 6127-6136. [CrossRef]

145. Shukla, V.; Bhatnagar, A.; Soni, P.K.; Vishwakarma, A.K.; Shaz, M.A.; Yadav, T.P.; Srivastava, O.N. Enhanced hydrogen sorption in a $\mathrm{Li}-\mathrm{Mg}-\mathrm{N}-\mathrm{H}$ system by the synergistic role of $\mathrm{Li}_{4}\left(\mathrm{NH}_{2}\right) 3 \mathrm{BH}_{4}$ and $\mathrm{ZrFe}_{2}$. Phys. Chem. Chem. Phys. 2017, 19, 9444-9456. [CrossRef] [PubMed]

146. Gamba, N.S.; Amica, G.; Arneodo Larochette, P.; Gennari, F.C. Interaction between $\mathrm{Li}_{2} \mathrm{Mg}(\mathrm{NH})_{2}$ and CO: Effect on the hydrogen storage behavior of the $\mathrm{Li}_{4}\left(\mathrm{NH}_{2}\right)_{3} \mathrm{BH}_{4}$ doped $\mathrm{Mg}\left(\mathrm{NH}_{2}\right)_{2}-2 \mathrm{LiH}$ composite. Int. J. Hydrogen Energy 2017, 42, 6024-6032. [CrossRef]

147. Cao, H.J.; Richter, T.M.M.; Pistidda, C.; Chaudhary, A.L.; Santoru, A.; Gizer, G.; Niewa, R.; Chen, P.; Klassen, T.; Dornheim, M. Ternary Amides Containing Transition Metals for Hydrogen Storage: A Case Study with Alkali Metal Amidozincates. Chemsuschem 2015, 8, 3777-3782. [CrossRef] [PubMed]

148. Cao, H.J.; Santoru, A.; Pistidda, C.; Richter, T.M.M.; Chaudhary, A.L.; Gizer, G.; Niewa, R.; Chen, P.; Klassen, T.; Dornheim, M. New synthesis route for ternary transition metal amides as well as ultrafast amide-hydride hydrogen storage materials. Chem. Commun. 2016, 52, 5100-5103. [CrossRef] [PubMed]

149. Cao, H.J.; Pistidda, C.; Richter, T.M.M.; Santoru, A.; Milanese, C.; Garroni, S.; Bednarcik, J.; Chaudhary, A.L.; Gizer, G.; Liermann, H.P.; et al. In Situ X-ray Diffraction Studies on the De/rehydrogenation Processes of the K-2 Zn( $\left.\mathrm{NH}_{2}\right)_{4}-8 \mathrm{LiH}$ System. J. Phys. Chem. C 2017, 121, 1546-1551. [CrossRef] 
150. Jepsen, L.H.; Wang, P.; Wu, G.; Xiong, Z.; Besenbacher, F.; Chen, P.; Jensen, T.R. Thermal decomposition of sodium amide, $\mathrm{NaNH}_{2}$, and sodium amide hydroxide composites, $\mathrm{NaNH}_{2}-\mathrm{NaOH}$. Phys. Chem. Chem. Phys. 2016, 18, 25257-25264. [CrossRef] [PubMed]

151. Jain, A.; Miyaoka, H.; Ichikawa, T. Two-Peak Mystery of $\mathrm{LiNH}_{2}-\mathrm{NaH}$ Dehydrogenation Is Solved? A Study of the Analogous Sodium Amide/Lithium Hydride System. J. Phys. Chem. C 2016, 120, 27903-27909. [CrossRef]

152. Sheppard, D.A.; Paskevicius, M.; Buckley, C.E. Hydrogen Desorption from the $\mathrm{NaNH}_{2}-\mathrm{MgH}_{2}$ System. J. Phys. Chem. C 2011, 115, 8407-8413. [CrossRef]

153. Dolotko, O.; Paulson, N.; Pecharsky, V.K. Thermochemical transformations in $2 \mathrm{MNH}_{2}-3 \mathrm{MgH}_{2}$ systems $(\mathrm{M}=\mathrm{Li}$ or Na). Int. J. Hydrogen Energy 2010, 35, 4562-4568. [CrossRef]

154. Yamaguchi, S.; Miyaoka, H.; Ichikawa, T.; Kojima, Y. Thermal decomposition of sodium amide. Int. J. Hydrogen Energy 2017, 42, 5213-5219. [CrossRef]

155. Garroni, S.; Delogu, F.; Bonatto Minella, C.; Pistidda, C.; Cuesta-Lopez, S. Mechanically activated metathesis reaction in $\mathrm{NaNH}_{2}-\mathrm{MgH}_{2}$ powder mixtures. J. Mater. Sci. 2017, 52, 11891-11899. [CrossRef]

156. Pireddu, G.; Valentoni, A.; Minella, C.B.; Pistidda, C.; Milanese, C.; Enzo, S.; Mulas, G.; Garroni, S. Comparison of the thermochemical and mechanochemical transformations in the $2 \mathrm{NaNH}_{2}-\mathrm{MgH}_{2}$ system. Int. J. Hydrogen Energy 2015, 40, 1829-1835. [CrossRef]

157. Singh, N.K.; Kobayashi, T.; Dolotko, O.; Wiench, J.W.; Pruski, M.; Pecharsky, V.K. Mechanochemical transformations in $\mathrm{NaNH}_{2}-\mathrm{MgH}_{2}$ mixtures. J. Alloys Compd. 2012, 513, 324-327. [CrossRef]

158. Xiong, Z.; Hu, J.; Wu, G.; Chen, P. Hydrogen absorption and desorption in $\mathrm{Mg}-\mathrm{Na}-\mathrm{N}-\mathrm{H}$ system. J. Alloys Compd. 2005, 395, 209-212. [CrossRef]

159. Jain, A.; Kumar, S.; Miyaoka, H.; Zhang, T.; Isobe, S.; Ichikawa, T.; Kojima, Y. Ammonia suppression during decomposition of sodium amide by the addition of metal hydride. Int. J. Hydrogen Energy 2017, 42, 22388-22394. [CrossRef]

160. Morelle, F.; Jepsen, L.H.; Jensen, T.R.; Sharma, M.; Hagemann, H.; Filinchuk, Y. Reaction Pathways in $\mathrm{Ca}\left(\mathrm{BH}_{4}\right)_{2}-\mathrm{NaNH}_{2}$ and $\mathrm{Mg}\left(\mathrm{BH}_{4}\right)_{2}-\mathrm{NaNH}_{2}$ Hydrogen-Rich Systems. J. Phys. Chem. C 2016, 120, 8428-8435. [CrossRef]

161. Bai, Y.; Zhao, L.-L.; Wang, Y.; Liu, X.; Wu, F.; Wu, C. Light-weight $\mathrm{NaNH}_{2}-\mathrm{NaBH}_{4}$ hydrogen storage material synthesized via liquid phase ball milling. Int. J. Hydrogen Energy 2014, 39, 13576-13582. [CrossRef]

162. Wu, C.; Bai, Y.; Yang, J.-h.; Wu, F.; Long, F. Characterizations of composite $\mathrm{NaNH}_{2}-\mathrm{NaBH}_{4}$ hydrogen storage materials synthesized via ball milling. Int. J. Hydrogen Energy 2012, 37, 889-893. [CrossRef]

163. Pei, Z.-W.; Wu, C.; Bai, Y.; Liu, X.; Wu, F. NaNH $\mathrm{NaBH}_{4}-\mathrm{NaB}_{4}$ hydrogen storage composite materials synthesized via liquid phase ball-milling: Influence of $\mathrm{Co}-\mathrm{Ni}-\mathrm{B}$ catalyst on the dehydrogenation performances. Int. J. Hydrogen Energy 2017, 42, 14725-14733. [CrossRef]

164. Lu, J.; Fang, Z.Z. Dehydrogenation of a Combined $\mathrm{LiAlH}_{4} / \mathrm{LiNH}_{2}$ System. J. Phys. Chem. B 2005, 109, 20830-20834. [CrossRef] [PubMed]

165. Jepsen, L.H.; Wang, P.; Wu, G.; Xiong, Z.; Besenbacher, F.; Chen, P.; Jensen, T.R. Synthesis and decomposition of $\mathrm{Li}_{3} \mathrm{Na}\left(\mathrm{NH}_{2}\right)_{4}$ and investigations of Li-Na-N-H based systems for hydrogen storage. Phys. Chem. Chem. Phys. 2016, 18, 1735-1742. [CrossRef] [PubMed]

166. Chua, Y.S.; Wu, G.; Xiong, Z.; Chen, P. Investigations on the solid state interaction between $\mathrm{LiAlH}_{4}$ and $\mathrm{NaNH}_{2}$. J. Solid State Chem. 2010, 183, 2040-2044. [CrossRef]

167. Dolotko, O.; Zhang, H.; Ugurlu, O.; Wiench, J.W.; Pruski, M.; Scott Chumbley, L.; Pecharsky, V. Mechanochemical transformations in $\mathrm{Li}(\mathrm{Na}) \mathrm{AlH}_{4}-\mathrm{Li}(\mathrm{Na}) \mathrm{NH}_{2}$ systems. Acta Mater. 2007, 55, 3121-3130. [CrossRef]

(C) 2018 by the authors. Licensee MDPI, Basel, Switzerland. This article is an open access article distributed under the terms and conditions of the Creative Commons Attribution (CC BY) license (http:/ / creativecommons.org/licenses/by/4.0/). 